\title{
Heterotrophic bacterial production and metabolic balance during the VAHINE mesocosm experiment in the New Caledonia lagoon
}

\author{
France Van Wambeke ${ }^{1}$, Ulrike Pfreundt ${ }^{2}$, Aude Barani ${ }^{1}$, Hugo Berthelot ${ }^{1}$, Thierry Moutin ${ }^{1}$, Martine Rodier $^{3, a}$, \\ Wolfgang R. Hess ${ }^{2}$, and Sophie Bonnet ${ }^{1,3}$ \\ ${ }^{1}$ Aix Marseille Université, CNRS/INSU, Université de Toulon, IRD, Mediterranean Institute of Oceanography (MIO) \\ UM110, 13288, Marseille, France \\ ${ }^{2}$ University of Freiburg, Faculty of Biology, Schaenzlestr. 1, 79104 Freiburg, Germany \\ ${ }^{3}$ Mediterranean Institute of Oceanography (MIO) - IRD/CNRS/Aix-Marseille University IRD Nouméa, 101 Promenade R. \\ Laroque, BPA5, 98848, Nouméa CEDEX, New Caledonia, France \\ ${ }^{a}$ now at: IRD, Université de la Polynésie française - Institut Malardé - Ifremer, UMR 241 Ecosystèmes Insulaires Océaniens \\ (EIO), IRD Tahiti, PB 529, 98713 Papeete, Tahiti, French Polynesia
}

Correspondence to: France Van Wambeke (france.van-wambeke@mio.osupytheas.fr)

Received: 24 November 2015 - Published in Biogeosciences Discuss.: 11 December 2015

Revised: 21 April 2016 - Accepted: 28 April 2016 - Published: 2 June 2016

\begin{abstract}
Studies investigating the fate of diazotrophs through the microbial food web are lacking, although $\mathrm{N}_{2}$ fixation can fuel up to $50 \%$ of new production in some oligotrophic oceans. In particular, the role played by heterotrophic prokaryotes in this transfer is largely unknown. In the frame of the VAHINE (VAriability of vertical and tropHIc transfer of diazotroph derived $\mathrm{N}$ in the south wEst Pacific) experiment, three replicate large-volume $\left(\sim 50 \mathrm{~m}^{3}\right)$ mesocosms were deployed for 23 days in the new Caledonia lagoon and were intentionally fertilized on day 4 with dissolved inorganic phosphorus (DIP) to stimulate $\mathrm{N}_{2}$ fixation. We specifically examined relationships between heterotrophic bacterial production (BP) and $\mathrm{N}_{2}$ fixation or primary production, determined bacterial growth efficiency and established carbon budgets. BP was statistically higher during the second phase of the experiment (P2: days 15-23), when chlorophyll biomass started to increase compared to the first phase (P1: days 5-14). Phosphatase alkaline activity increased drastically during the second phase of the experiment, showing adaptations of microbial populations after utilization of the added DIP. Notably, among autotrophs, Synechococcus abundances increased during P2, possibly related to its capacity to assimilate leucine and to produce alkaline phosphatase. Bacterial growth efficiency based on the carbon budget (27-43\%), was notably higher than generally cited for oligotrophic environments and discussed in links
\end{abstract}

with the presence of abundant species of bacteria expressing proteorhodopsin. The main fates of gross primary production (particulate + dissolved) were respiration $(67 \%)$ and export through sedimentation (17\%). BP was highly correlated with particulate primary production and chlorophyll biomass during both phases of the experiment but was slightly correlated, and only during $\mathrm{P} 2$ phase, with $\mathrm{N}_{2}$ fixation rates. Heterotrophic bacterial production was strongly stimulated after mineral $\mathrm{N}$ enrichment experiments, suggesting $\mathrm{N}$-limitation of heterotrophic bacteria across the experiment. $\mathrm{N}_{2}$ fixation rates corresponded to $17-37 \%$ of the nitrogen demand of heterotrophic bacteria. Our results suggest that most of the diazotroph-derived nitrogen fuelled the heterotrophic bacterial community through indirect processes generating dissolved organic matter and detritus, like mortality, lysis and grazing of both diazotrophs and non-diazotrophs.

\section{Introduction}

In the south-west Pacific ocean, the natural occurrence of abundant and diverse plankton taxa capable of dinitrogen $\left(\mathrm{N}_{2}\right)$ fixation $\left(\mathrm{N}_{2}\right.$-fixing or diazotrophic organisms; e.g., Moisander et al., 2010) can fuel $\sim 50 \%$ of new primary production (Garcia et al., 2007; Bonnet et al., 2015). However, little is known about the fate of the diazotroph-derived nitro- 
gen (DDN) in this environment (Bonnet et al., 2016b). In particular, the role played by the microbial food web, and among them the heterotrophic bacteria in the transformation of DDN is largely unknown. In the central gyre of the South Pacific, where $\mathrm{N}_{2}$ fixation is lower than in the south-west Pacific, nitrogen is the first element limiting growth of both phytoplankton and heterotrophic bacterioplankton as observed in short-term nutrient enrichment experiments (Bonnet et al., 2008; Van Wambeke et al., 2008a) or incubations with ${ }^{15} \mathrm{~N}$ leucine or ${ }^{15} \mathrm{~N}_{-} \mathrm{NH}_{4}^{+}$, which significantly enhanced bicarbonate uptake (Halm et al., 2012). Such competition for nitrogen influences dissolved organic carbon accumulation in the surface layers and export. In the south-west Pacific, however, the phytoplankton-heterotrophic bacterial coupling has mainly been investigated in the New Caledonia Lagoon. In this system, phytoplankton and bacterial production show seasonal patterns, with maxima in December-January and annual bacterial production representing 21 to $34 \%$ of particulate primary production (Torréton et al., 2010). In the oligotrophic stations of the lagoon, based on a bacterial growth efficiency of $10 \%$ or less, dissolved phytoplankton release was not sufficient to sustain bacterial carbon demand (Rochelle-Newall et al., 2008). N-limitation of primary production is expected based on year-round dissolved inorganic nitrogen (DIN) to dissolved inorganic phosphorus (DIP) ratios and silicates to DIN ratios, which are respectively lower and higher than Redfield ratios (Torréton et al., 2010). However, $\mathrm{N}_{2}$ fixation is a recurrent feature in the lagoon (Garcia et al., 2007; Biegala and Raimbault, 2008), and no information is available on the potential role played by this process on the functioning of the microbial food web and how it could influence the factors limiting heterotrophic bacterial production. As blooms of diazotrophs are transient events, the production of varying sources and quality of organic matter is expected, which may influence biogeochemical fluxes, in particular heterotrophic bacterial production.

Through the VAHINE (VAriability of vertical and tropHIc transfer of diazotroph derived $\mathrm{N}$ in the south wEst Pacific) programme (http://mio.pytheas.univ-amu.fr/ ?VAHINE-Project; Bonnet et al., 2016b), we experimentally investigated the fate of DDN in the planktonic food web and its potential impact on particle export. For this, we studied the development and the fate of a diazotroph bloom enhanced by intentional fertilization with DIP in large-volume $\left(\sim 50 \mathrm{~m}^{3}\right)$ mesocosms deployed in the oligotrophic part of the New Caledonian lagoon, DIP being considered to control the nitrogen input by dinitrogen fixation in the SW Pacific upper surface waters (Moutin et al., 2005, 2008). The VAHINE experiment provided a unique opportunity to study such phytoplankton-heterotrophic bacteria interactions by simultaneously using biogeochemical techniques to assess stocks and fluxes in the same body of water for a period of three weeks. In particular, our objectives were (i) to explore factors controlling heterotrophic bacterial growth, (ii) to examine the links between heterotrophic bacterial production and the activity of $\mathrm{N}_{2}$-fixing organisms and primary producers and (iii) to study the fate of carbon inside mesocosms and the balance of autotrophy vs. heterotrophy. The factors controlling heterotrophic bacterioplankton were studied using short-term nutrient enrichment experiments and measurements of alkaline phosphatase activity. In oligotrophic systems, assimilation of organic nitrogen-containing molecules can also confer advantage for growth to some cyanobacteria (Zubkov et al., 2004; Mary et al., 2008a). Thus we quantified fluxes of leucine incorporation on a single cell basis, using flow sorting by cytometry (Talarmin et al., 2011).

\section{Material and methods}

\subsection{Mesocosm description and sampling strategy}

Three large mesocosms $\left(\sim 50 \mathrm{~m}^{3}\right)$ were deployed as open tubes with unfiltered, nutrient-poor waters of the Nouméa lagoon close to the Boulari passage $\left(22^{\circ} 29.073 \mathrm{~S}-\right.$ $166^{\circ} 26.205 \mathrm{E}$ ) located $28 \mathrm{~km}$ of the coast from 13 January to 4 February 2013 (Fig. 1). After two days of stabilizing mixing and verticality of the mesocosms, they were closed at the bottom, which constituted the starting day of the experiment, and a sediment trap was screwed at the basis of the bottom cone of each mesocosm and changed every morning by scuba divers. The mesocosm design is based on Guieu et al. (2010) and the choice of the site in the lagoon, deployment and sampling strategy are described in details in Bonnet el al. (2016b). The three triplicate mesocosms were supple-

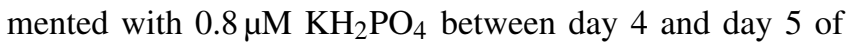
the experiment to alleviate potential $\mathrm{P}$ limitation and induce a bloom of naturally present communities of $\mathrm{N}_{2}$ fixing organisms. All samples for the parameters described below were collected every morning for 23 days using a clean Teflon pumping system from three selected depths (1, 6 and $12 \mathrm{~m})$ in each mesocosm (M1, M2 and M3) and in surrounding waters (i.e. outside the mesocosms, hereafter called Nouméa lagoon waters). Seawater from each mesocosm was first filled in a polypropylene $50 \mathrm{~L}$ tank for stocks measurements, $4.5 \mathrm{~L}$ polycarbonate bottles for rates measurements and $10 \mathrm{~L}$ carboys for diversity. All carboys were immediately transferred onto the R/V Alis anchored close to the mesocosms to serve as a lab platform to ensure a quick processing of the samples (cruise doi link: doi:10.17600/13100010). Subsampling procedure and analysis for inorganic nutrients, chlorophyll $a$ (Chl) and their associated phaeopigments, DIP turnover time and $\mathrm{N}_{2}$ fixation rates are detailed in a companion paper (Berthelot et al., 2015). Primary production (PP) was determined from short-term $(\sim 4 \mathrm{~h})$ incubations around noon with $\mathrm{H}^{14} \mathrm{CO}_{3}$ (see details in Berthelot et al., 2015) and a model of photosynthesis applied to calculate daily fluxes (Moutin et al., 1999). This model allows estimation of $24 \mathrm{~h}$ fluxes (dawn to dawn) from hourly rates, independent of starting time or duration of incubations, of the geographic origin of 

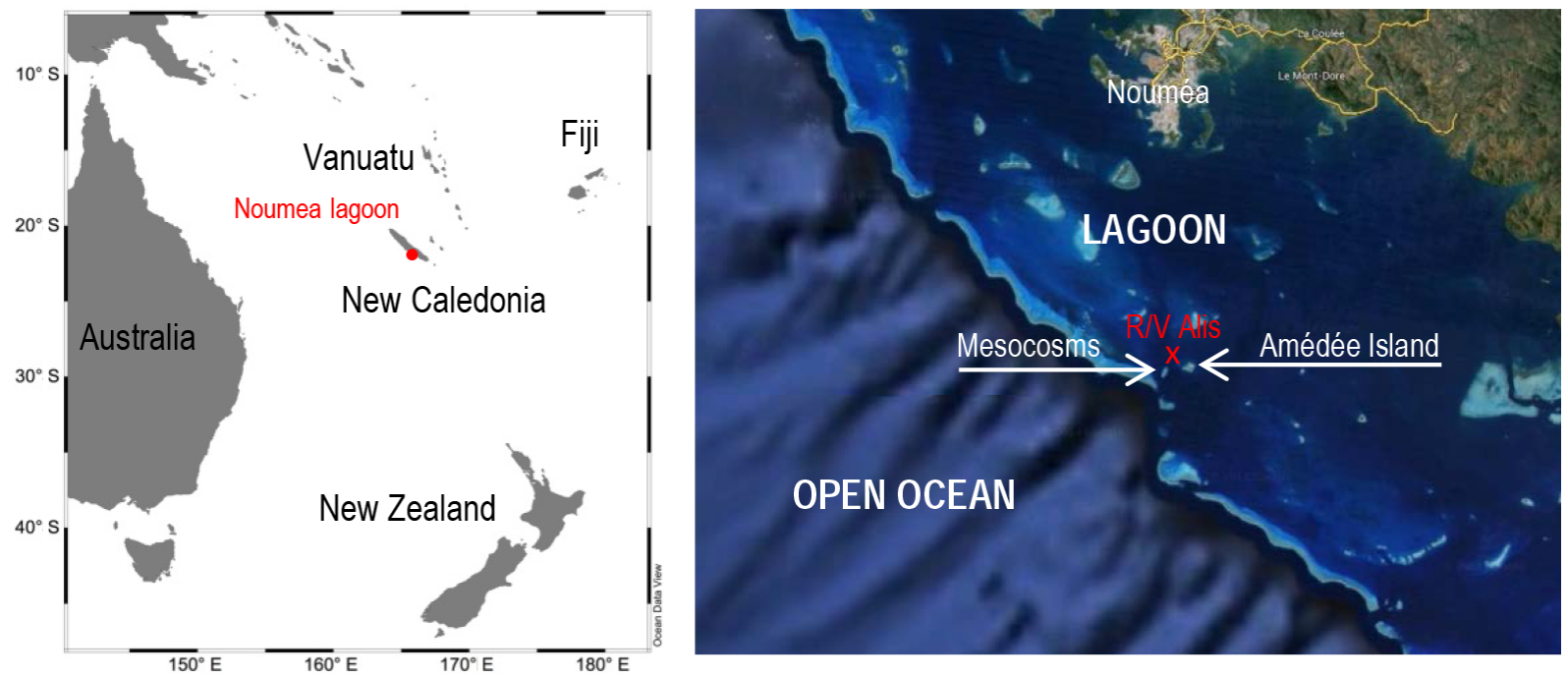

Figure 1. Position of mesocosms implemented in the south-west lagoon of New Caledonia.

the samples or of the time of the year (i.e. systems with varying dark-light periods). This model avoids the general biases introduced by the large variety of incubation conditions used in the Steeman-Nielsen (1952) ${ }^{14} \mathrm{C}$ methodology (Regaudiede-Gioux et al., 2014 and references therein). Another advantage of this model is that it allows estimation of both PP $(24 \mathrm{~h}$ dawn to dawn) and gross primary production (GPP). For $24 \mathrm{~h}$ incubations, GPP is $1.72 \times \mathrm{PP}$ as determined from the model (Fig. 5 in Moutin et al., 1999). This constant is applicable as long as $24 \mathrm{~h}$-fluxes (dawn to dawn) are calculated using the same model.

\subsection{Heterotrophic bacterioplankton abundances}

Flow-cytometry analyses were carried out at the flowcytometry platform of the laboratory (https://precym.mio. univ-amu.fr/). Samples were analysed using a FACSCalibur (BD Biosciences, San Jose, CA). For heterotrophic bacterial abundance (BA), $1.8 \mathrm{~mL}$ of seawater was fixed with formaldehyde ( $2 \%$ final concentration, 15 min incubation at $\mathrm{RT}$, room temperature), frozen and stored in liquid $\mathrm{N}_{2}$ until analysis in the laboratory. After thawing at RT, $0.3 \mathrm{~mL}$ of each sample was incubated with SYBR Green II (Molecular Probes, final conc. $0.05 \%[v / v]$ ) for $15 \mathrm{~min}$ at RT in the dark to stain nucleic acids (Marie et al., 1997). Cells were characterized by two main optical signals collected from the $488 \mathrm{~nm}$ laser: side scatter (SSC, related to cell structure) and green fluorescence $\left(530 / 40_{488} \mathrm{~nm}\right)$, related to nucleic acids staining. For the calculation of heterotrophic prokaryotes abundances, phytoplankton, in particular Prochlorococcus and Synechococcus, were gated out due to its red autofluorescence induced by the chlorophyll (Sieracki et al., 1995). We discriminated HNA (high nucleic acid) and LNA (low nucleic acid) cells and heterotrophic bacterial abundance (HBA) was calculated as the sum of both categories. Tru-
Count beads (BD Biosciences) and $2 \mu \mathrm{m}$ beads (Fluoresbrite YG, Polyscience) were added to the samples just before analysis. To determine the volume analysed by the flow cytometer, the flow rate was estimated by weighing three tubes of samples before and after a 3 min run. The cell abundance was determined by dividing the number of cells by the volume analysed, determined both by the TruCount beads and flow rate. All data were collected in log scale and stored in listmode using the CellQuest software (BD Biosciences). Data analysis was performed using the SUMMIT v4.3 software (Dako).

\subsection{Heterotrophic bacterial production}

Heterotrophic bacterial production (BP) was estimated daily using the ${ }^{3} \mathrm{H}$-leucine incorporation technique (Kirchman, 1993), adapted from the centrifuge method (Smith and Azam, 1992). For each sample, triplicate aliquots $(1.5 \mathrm{~mL}$ each) and one $1.5 \mathrm{~mL}$ control, killed with trichloracetic acid (TCA), were incubated with a mix of $6 \mathrm{nM}$ hot leucine $\left(\mathrm{L}-{ }^{3} \mathrm{H}\right]$ leucine, Perkin Elmer ${ }^{\circledR}$ specific activity ranging $106 \mathrm{Ci} \mathrm{mmole}^{-1}$ ) and $14 \mathrm{nM}$ cold leucine, at in situ surface temperature (on-deck incubators equipped with $50 \%$ light intensity screen and cooled with circulating surface seawater), for $1 \mathrm{~h}$. Linearity of leucine incorporation was checked regularly by time series experiments. The live incubations were terminated with 5\% TCA (final concentration). After three runs of centrifugation/aspiration of the supernatant (once with the fixed sea water sample, once with a $5 \%$ TCA rinse and once with an $80 \%$ ethanol rinse), the pellet was resuspended in Packard Ultima Gold MW Scintillation liquid $^{\circledR}$. Radioactivity was counted using a Liquid Scintillation Analyzer Packard ${ }^{\circledR}$ 1600TR and the ${ }^{3} \mathrm{H}$ counting efficiency was corrected for quenching. Concentration kinetic experiments showed that isotopic dilution factor ranged from 


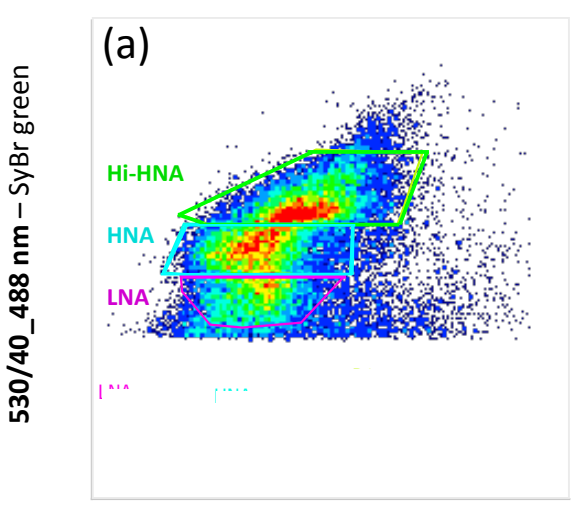

SSC_488 nm- size

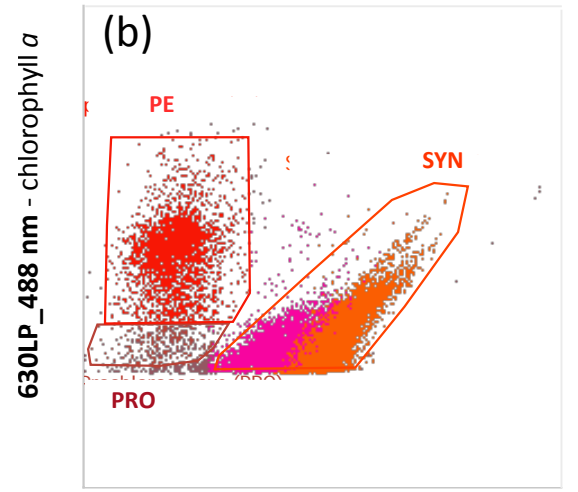

580/30_488 $\mathrm{nm}$ - phycoerythrin

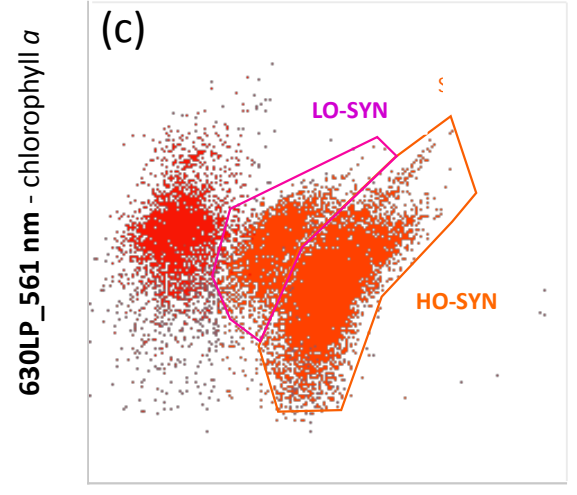

580/30_488 ñîn - phycoerythrin

Figure 2. Example (day $23 \mathrm{M} 31 \mathrm{~m}$ ) of flow-cytometry cytogram dot plot of (a) naturally non-fluorescent bacterioplankton groups discriminated by their DNA content (SYBR green-induced fluorescence in arbitrary units (a.u.) vs. cell size (side scatter), after $488 \mathrm{~nm}$ laser excitation); (b) phototrophic groups discriminated by their chlorophyll $a$ content (related to the red fluorescence intensity (a.u.) vs. phycoerythrin related to the orange fluorescence intensity (a.u.) after $488 \mathrm{~nm}$ laser excitation); (c) low-orange (LO-SYN) and high-orange (HO-SYN) Synechococcus-like subgroups separated by their chlorophyll $a$ content (after $561 \mathrm{~nm}$ laser excitation) vs. their phycoerythrin content (after $488 \mathrm{~nm}$ laser excitation).

1 to 1.56 and thus BP rates were calculated from leucine incorporation rates using conversion factor adjusted from 1.5 to $2.4 \mathrm{~kg} \mathrm{C}$ mole $^{-1}$ leucine. Daily rates were calculated assuming they are 24 times the hourly rate.

\subsection{Nutrient addition experiments}

The availability of phosphorus $(\mathrm{P})$, nitrogen $(\mathrm{N})$ and organic carbon (C) for heterotrophic bacteria was investigated by measuring changes in bacterial production following additions of DIP $(0.25 \mu \mathrm{M} \mathrm{P}), \mathrm{NO}_{3}^{-}$and $\mathrm{NH}_{4}^{+}(1 \mu \mathrm{M}$ each) or glucose $(10 \mu \mathrm{M} \mathrm{C}$; final concentrations). Two bioassays were realized: one right before (day 4) and one two weeks after (day 20) the DIP fertilization in M1 (samples from $1 \mathrm{~m}$ depth). Eight combinations were tested (P, N, C, PN, PC, NC and $\mathrm{PNC}$ ) including the non-enriched control T. Each bioassay condition was tested in triplicate in $60 \mathrm{~mL}$ polycarbonate bottles incubated for $48 \mathrm{~h}$ under in situ-simulated conditions in the on-deck incubator (described in Sect. 2.3). After incubation, each bottle was subsampled in order to measure BP using the leucine technique described in Sect. 2.3.

\subsection{Alkaline phosphatase activity}

Total alkaline phosphatase activity (APA) was measured at the three depths in M1, M2 and M3 and in Nouméa lagoon waters using the analog substrate methylumbelliferone phosphate (MUF-P, $1 \mu \mathrm{M}$ final concentration; Hoppe, 1983). The linear increase in fluorescence of seawater with added MUF was measured over the incubation time (up to $8 \mathrm{~h}$ ), in the dark with a TKO 100 Hoefer DNA fluorometer (singlewavelength with excitation/emission fixed at $365 / 460 \mathrm{~nm}$ but suitable for MUF). Concentration kinetics using a range from 25 to 2500 nM MUF-P were run on some occasions to check that the $1 \mu \mathrm{M}$ concentration used for routine measurements was sufficient to saturate enzyme activity. Blanks were run by adding the MUF-P to filtered boiled seawater and were shown to be insignificant. Calibration curves were made with MUF standards.

\subsection{Statistical analyses}

Non-parametric Mann-Whitney and Kruskal-Wallis tests were used to compare differences of each parameter studied between mesocosms, periods of time or effects of various amendments on BP in the nutrient addition experiments. Model I linear regressions and Pearson correlation coefficient were used to study log-log relationships between BP and Chl or PP; and evolution of DOC and POC with time.

\section{Results}

Salinity and temperature measurements show that the water column was not stratified over the course of the experiment, except in the first two days, which were characterized by a slight stratification both inside and outside of the mesocosms (Bonnet et al., 2016b). No vertical stratification was observed in the mesocosms for bacterial production or alkaline phosphatase activity (APA; see exemplary data for M1 in Supplement Fig. S1) as for most of the parameters (Bonnet et al., 2016b; Turk-Kubo et al., 2015; Berthelot et al., 2015). For all descriptions of biogeochemical stocks and fluxes, we thus used the average of the three depths to plot the temporal evolution within each mesocosm. 

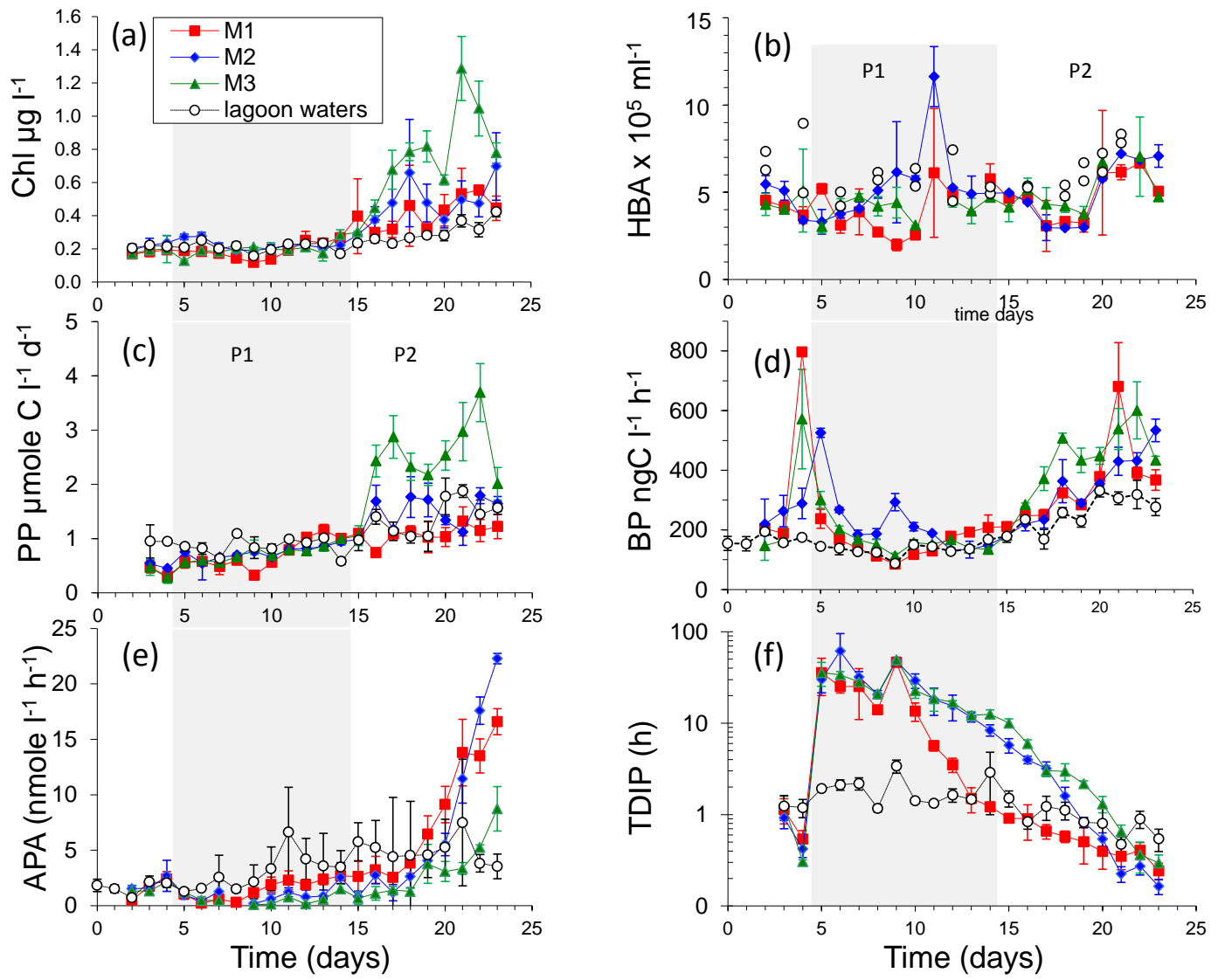

Figure 3. Evolution of (a) chlorophyll $a(\mathrm{Chl})$, (b) heterotrophic bacterial abundance (HBA), (c) primary production (PP), (d) heterotrophic bacterial production (BP), (e) alkaline phosphatase activity (APA) and (f) DIP turnover time (TDIP) in the three mesocosms M1, M2, M3 and in the lagoon waters (lagoon). Each point is the mean of the three depths sampled, error bars are standard deviations. For lagoon HBA, only data from 1 and $12 \mathrm{~m}$ depth are available occasionally and discrete data are presented instead.

\subsection{Chlorophyll stocks and net primary production}

Based on the Chl and PP dynamics, two periods P1 (days 5-14) and P2 (days 15-23) were identified after DIP fertilization, which were also identified by Berthelot et al. (2015) based on biogeochemical characteristics and by Turk-Kubo et al. (2015) based on changes in abundances of targeted diazotrophs. Diatom heterocyst-forming symbionts associated with diatoms were abundant during $\mathrm{P} 1$, while a bloom of the unicellular $\mathrm{N}_{2}$-fixing cyanobacteria from Group C (UCYNC) occurred for P2 (Leblanc et al., 2016; Turk-Kubo et al., 2015). Chl stocks significantly increased during P2 compared to P1 in the three mesocosms (statistics are presented in Table 1). Chl concentrations during P2 in all three mesocosms were significantly higher than those in the Nouméa lagoon for the same period. PP showed the same trend as for Chl, being higher during P2 in all three mesocosms (Fig. 3, Table 1). However, the PP rates and Chl concentrations reached during $\mathrm{P} 2$ were not identical between the three mesocosms: M3 exhibited higher $\mathrm{Chl}$ concentrations during P2 $\left(0.71 \pm 0.30 \mu \mathrm{g} \mathrm{L}^{-1}\right)$ than M2 $(0.49 \pm 0.18 \mu \mathrm{g}$
$\left.\mathrm{L}^{-1}\right)$ and $\mathrm{M} 1\left(0.42 \pm 0.14 \mu \mathrm{g} \mathrm{L}^{-1}, p<0.001\right)$. This was equally true for PP rates $\left(2.45 \pm 0.76 \mu\right.$ mole $\mathrm{CL}^{-1} \mathrm{~d}^{-1}$ in M3 compared to $1.47 \pm 0.35 \mu$ mole $\mathrm{CL}^{-1} \mathrm{~d}^{-1}$ in $\mathrm{M} 2$ and $1.09 \pm 0.22 \mu$ mole $\mathrm{CL}^{-1} \mathrm{~d}^{-1}$ in M1, $p<0.001$ ). Significant increases of $\mathrm{Chl}$ and $\mathrm{PP}$ were also observed in lagoon waters (reaching in P2 $0.30 \pm 0.07 \mu \mathrm{g} \mathrm{Chl} \mathrm{L}{ }^{-1}$ and $1.36 \pm 0.37 \mu$ mole $\mathrm{CL}^{-1} \mathrm{~d}^{-1}$, respectively, Table 1 ).

\subsection{Heterotrophic bacterioplankton abundance and production}

Abundances of heterotrophic bacterioplankton (HBA) varied 10-fold, from 1.7 (day 9, M1, $1 \mathrm{~m}$ ) to $12.8 \times 10^{5}$ cells $\mathrm{mL}^{-1}$ (M2, day 11, $6 \mathrm{~m}$ ). Peaks of HBA were sporadic, like on day 11 in M1, but not repeated for the three depths sampled. They were possibly due to the presence of a patchy distribution of aggregates that could have biased some of the results. These peaks are occasional, and as they might reflect the reality of a patchy distribution, they were kept in the figures, statistics and estimates of means per day. Average HBA did not increase statistically between phase P1 and $\mathrm{P} 2$ in M1 and M2 but increased slightly $(p<0.05)$ from 
Table 1. Averages \pm standard deviations of some parameters during phases P1 (from day 5 to day 14) and P2 (from day 15 to day 23 ) in the three mesocosms M1, M2, M3 and in the lagoon waters. HBA: heterotrophic prokaryotic abundances, BP: heterotrophic prokaryotic production, APA: alkaline phosphatase activity, TDIP: turnover time of DIP. $\mathrm{N}_{2}$ fixation contribution to BP $\left(\mathrm{N}_{2}\right.$ fix / BP ratio, in \%) is based on a $\mathrm{C} / \mathrm{N}$ of 6.8 for heterotrophic bacteria.

\begin{tabular}{|c|c|c|c|c|}
\hline & M1 P1 & M1 P2 & Lagoon P1 & Lagoon P2 \\
\hline $\operatorname{Chl}\left(\mu \mathrm{gL}^{-1}\right)$ & $0.19 \pm 0.05^{* * *}$ & $0.42 \pm 0.14$ & $0.21 \pm 0.03^{* * *}$ & $0.30 \pm 0.07$ \\
\hline$\%$ pheopigments & $24 \pm 3^{* * *}$ & $28 \pm 5$ & $23 \pm 6$ & $26 \pm 3$ \\
\hline $\mathrm{HBA}\left(\times 10^{5}\right.$ cells $\left.\mathrm{mL}^{-1}\right)$ & $3.9 \pm 1.9$ & $4.5 \pm 1.7$ & $5.5 \pm 0.95$ & $6.2 \pm 1.2$ \\
\hline $\mathrm{PP}\left(\mu\right.$ mole $\left.\mathrm{CL}^{-1} \mathrm{~d}^{-1}\right)$ & $0.71 \pm 0.27^{* * *}$ & $1.09 \pm 0.22$ & $0.85 \pm 0.17^{* * *}$ & $1.36 \pm 0.37$ \\
\hline $\mathrm{BP}\left(\mathrm{ng} \mathrm{CL} \mathrm{L}^{-1} \mathrm{~h}^{-1}\right)$ & $157 \pm 49^{* * *}$ & $348 \pm 42$ & $135 \pm 24^{* * *}$ & $256 \pm 60$ \\
\hline $\mathrm{DOC} \mu \mathrm{MC}$ & $59 \pm 3$ & $60 \pm 2$ & $60 \pm 3$ & $60 \pm 2$ \\
\hline $\mathrm{POC} \mu \mathrm{MC}$ & $8 \pm 3^{*}$ & $9 \pm 1$ & $6.6 \pm 1.1^{* *}$ & $7.6 \pm 1.3$ \\
\hline APA (nmole MUF-P hydr $\mathrm{L}^{-1} \mathrm{~h}^{-1}$ ) & $1.5 \pm 0.9^{* * *}$ & $8.0 \pm 5.4$ & $3.0 \pm 2.3^{* *}$ & $5.0 \pm 3.1$ \\
\hline TDIP (days) & $16 \pm 15^{* * *}$ & $0.5 \pm 0.3$ & $2.0 \pm 0.9^{* * *}$ & $0.9 \pm 0.4$ \\
\hline $\mathrm{BP} / \mathrm{PP}$ ratio & $0.48 \pm 0.18^{* * *}$ & $0.65 \pm 0.20$ & $0.33 \pm 0.11^{*}$ & $0.39 \pm 0.10$ \\
\hline \multirow[t]{2}{*}{$\mathrm{N}_{2}$ fix / BP ratio (\%) } & $21 \pm 11^{*}$ & $29 \pm 16$ & $22 \pm 13^{*}$ & $15 \pm 8$ \\
\hline & M2 P1 & M2 P2 & M3 P1 & M3 P2 \\
\hline $\operatorname{Chl}\left(\mu \mathrm{g} \mathrm{L}^{-1}\right)$ & $0.22 \pm 0.03^{* * *}$ & $0.49 \pm 0.18$ & $0.20 \pm 0.04^{* * *}$ & $0.71 \pm 0.30$ \\
\hline$\%$ pheopigments & $23 \pm 2^{* * *}$ & $28 \pm 6$ & 232 & $26 \pm 15$ \\
\hline $\mathrm{HBA}\left(\times 10^{5}\right.$ cells $\left.\mathrm{mL}^{-1}\right)$ & $2.2 \pm 2.2$ & $4.9 \pm 1.8$ & $4.1 \pm 0.7^{*}$ & $5.0 \pm 1.4$ \\
\hline $\mathrm{PP}\left(\mu\right.$ mole $\left.\mathrm{CL}^{-1} \mathrm{~d}^{-1}\right)$ & $0.75 \pm 0.15^{* * *}$ & $1.47 \pm 0.35$ & $0.73 \pm 0.15^{* * *}$ & $2.45 \pm 0.76$ \\
\hline 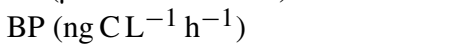 & $227 \pm 114^{* * *}$ & $338 \pm 116$ & $168 \pm 52^{* * *}$ & $422 \pm 132$ \\
\hline $\mathrm{DOC} \mu \mathrm{MC}$ & $58 \pm 3^{* *}$ & $61 \pm 1$ & $61 \pm 3$ & $60 \pm 2$ \\
\hline $\mathrm{POC} \mu \mathrm{MC}$ & $10 \pm 3$ & $9 \pm 1$ & $9 \pm 2^{* * *}$ & $13 \pm 3$ \\
\hline APA (nmole MUF-P hydr $\mathrm{L}^{-1} \mathrm{~h}^{-1}$ ) & $1.0 \pm 0.8^{* * *}$ & $7.6 \pm 7.6$ & $0.6 \pm 0.5^{* * *}$ & $3.18 \pm 2.61$ \\
\hline TDIP (days) & $27 \pm 19^{* * *}$ & $1.8 \pm 2.0$ & $25 \pm 12^{* * *}$ & $3.0 \pm 3.1$ \\
\hline $\mathrm{BP} / \mathrm{PP}$ ratio & $0.65 \pm 0.41$ & $0.47 \pm 0.16$ & $0.50 \pm 0.24^{*}$ & $0.35 \pm 0.08$ \\
\hline $\mathrm{N}_{2}$ fix / BP ratio (\%) & $17 \pm 16^{* * *}$ & $30 \pm 18$ & $25 \pm 15$ & $22 \pm 11$ \\
\hline
\end{tabular}

Mann-Whitney tests were performed to test significant differences between P1 and P2: ${ }^{*} p<0.05 ;{ }^{* *} 0.01<p<0.05 ;{ }^{* * *} p<0.001$.

$(4.1 \pm 0.7)$ to $(5.0 \pm 1.4) \times 10^{5}$ cells $\mathrm{mL}^{-1}$ in $\mathrm{M} 3$ (Table 1 , Fig. 3). Evolution of BP in the mesocosms was close to that in lagoon waters during P1, except for a peak only detected on day 4 (the morning before DIP fertilization) in M1 and $\mathrm{M} 3$, and at day 5 in M2. These peaks were not related to any HBA, Chl or PP increase but were related to a steep increase in Rhodobacteraceae 16S ribosomal RNA genes (Pfreundt et al., 2016b). Just like PP, BP significantly increased during $\mathrm{P} 2$ in all three mesocosms with higher values in M3 compared to M1 and M2 during P2 (KruskalWallis test, $p<0.05)$. This BP increase was also observed in lagoon waters but with lower amplitude (Table 1). In the three mesocosms, the $\log -\log$ relationship between BP and PP was significant only during $\mathrm{P} 2(r=0.54, p<0.001)$, whereas that between $\mathrm{BP}$ and $\mathrm{Chl}$ was significant during $\mathrm{P} 1$ and P2 $(r=0.4, p<0.001$ and $r=0.72, p<0.001$, respectively, Fig. 4). In lagoon waters, the BP / PP ratio slightly increased (but significantly) between P1 and P2 ( 0.33 to 0.39 , $p<0.05$, Table 1$)$. The $\mathrm{BP} / \mathrm{PP}$ ratio significantly increased during P2 in M1 $(0.48$ to $0.65, p<0.001)$, significantly decreased in M3 $(0.50$ to $0.35, p<0.05)$ and remained stable in M2 (Table 1). Such differences probably depended on vary- ing maximal values of PP in different mesocosms and the exact days when PP or BP started to increase. Thus we examined the trend of $\mathrm{BP} / \mathrm{PP}$ ratio with $\mathrm{PP}$, keeping in mind the risk of autocorrelation. BP / PP ratio decreased when PP increased, with higher intensities in the mesocoms compared to lagoon waters, and was consistent for P1 or P2 (Table 2). The $\log -\log$ relationship between $\mathrm{N}_{2}$ fixation rates $\left(\mathrm{nM} \mathrm{d}^{-1}\right)$ and $\mathrm{BP}\left(\mathrm{mg} \mathrm{C} \mathrm{m}^{-3} \mathrm{~d}^{-1}\right)$ was insignificant during P1 and significant during $\mathrm{P} 2\left(\log (\mathrm{BP})=0.13 \times \log \left(\mathrm{N}_{2}\right.\right.$ fix rates $)+0.73$, $r=0.21, p=0.04$, data not shown).

\subsection{Alkaline phosphatase activity}

APA was homogeneous between the three depths sampled from the mesocosms (example for M1 on Fig. S1), but this was not the case in the Nouméa lagoon, where activity was often higher at $1 \mathrm{~m}$ depth compared to the two other depths (data not shown). A slight but very reproducible decrease of APA occurred on days 5 and 6 in all three mesocosms where DIP fertilization took place and in lagoon waters only on day 5 (Fig. 3). DIP was consumed more rapidly in M1, mirrored by higher APA and lower TDIP between day 9 and 18 in this mesocosm (Fig. 3). APA then increased very rapidly in M1 
Table 2. Log-log relationships between BP / PP ratio and PP (expressed in $\mathrm{mgC} \mathrm{m}^{-3} \mathrm{~d}^{-1}$ ). In mesocosms, phase P1 and P2 are separated for the regressions. $r$ : Pearson correlation coefficient, $p$ : probability.

\begin{tabular}{llll}
\hline & Equation & $r$ & $p$ \\
\hline Phase P1 & $\log (\mathrm{BP} / \mathrm{PP})=-0.87 \times \log (\mathrm{PP})+0.49$ & 0.59 & $<0.001$ \\
Phase P2 & $\log (\mathrm{BP} / \mathrm{PP})=-0.53 \times \log (\mathrm{PP})+0.33$ & 0.6 & $<0.001$ \\
Lagoon waters & $\log (\mathrm{BP} / \mathrm{PP})=-0.24 \times \log (\mathrm{PP})-0.19$ & 0.28 & $<0.01$ \\
\hline
\end{tabular}

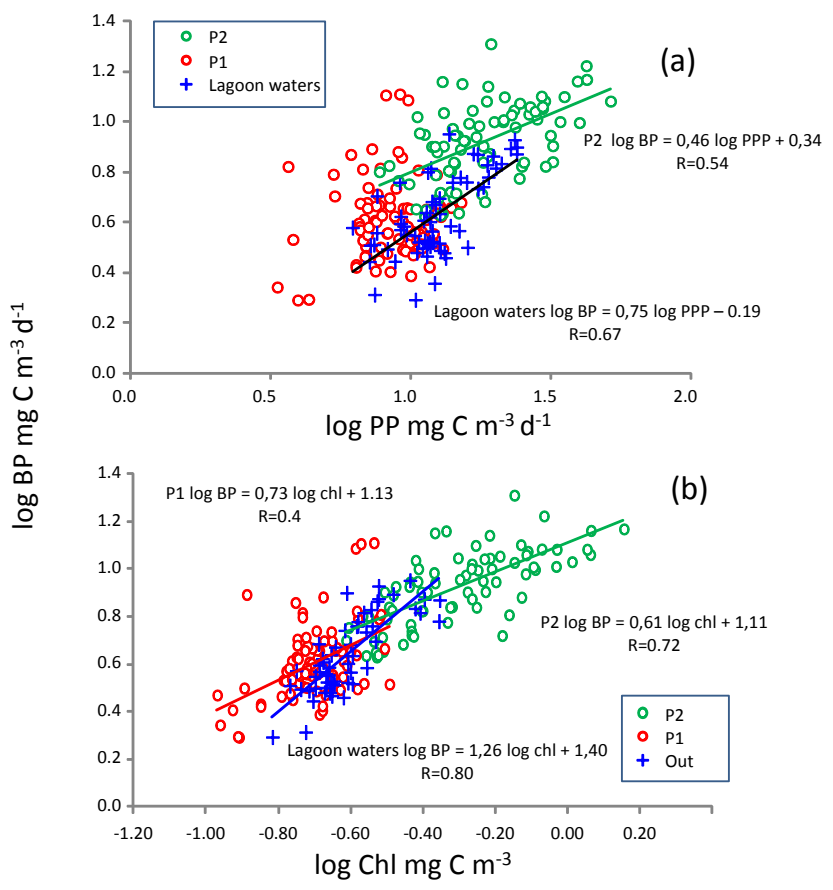

Figure 4. Log-log relationships between heterotrophic bacterial production (BP) and (a) primary production (PP) or (b) chlorophyll $a(\mathrm{Chl})$.

and M2 after day 17, but only after day 21 in M3. Such delays were in agreement with the evolution of DIP, which was less rapidly consumed in M3 compared to M1 and M2 (Berthelot et al., 2015). Consequently, although mean APA increased significantly in all three mesocosms between P1 and P2 (Table 1), it was lower in M3 compared to M1 and M2 during P2 (3.1 vs. 7.5-7.9 nmole MUF-P hydrolyzed $\mathrm{L}^{-1} \mathrm{~h}^{-1}$, respectively, $p<0.01)$. Finally, APA also increased significantly between $\mathrm{P} 1$ and $\mathrm{P} 2$ in the lagoon waters, albeit to a lower extent as in the mesocosms (from 3 to 5 nmole MUFPhydrolyzed $\mathrm{L}^{-1} \mathrm{~h}^{-1}$, Table 1 ). It is noteworthy that APA in the lagoon waters exhibited the strongest increase between day 10 and 11 and stayed at this higher level until day 23, thus exhibiting different dynamics than in the mesocosms.

\subsection{Enrichment experiments}

In the two $48 \mathrm{~h}$ nutrient enrichment experiments performed on day 4 and on day 20, BP increased 3-fold after nitrogen
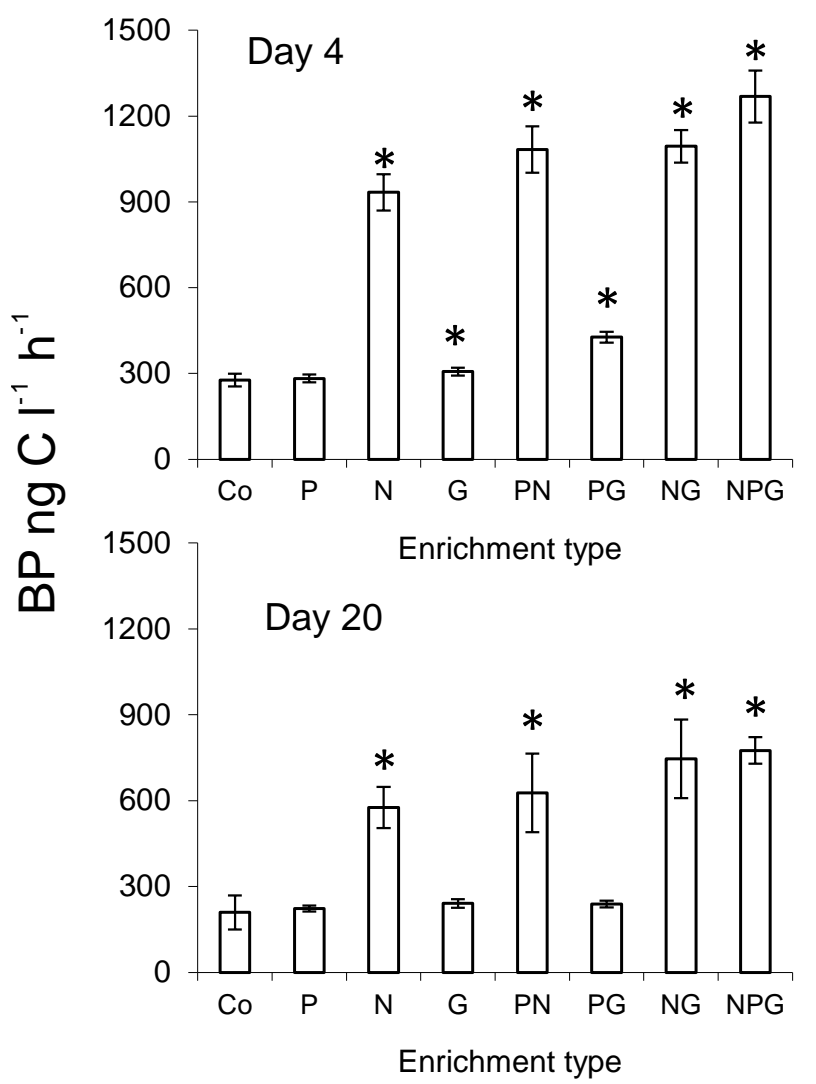

Figure 5. Response of heterotrophic bacterial production to the enrichment experiments conducted on days 2 and 20. Asterisks show significant responses in comparison to the unamended control $(\mathrm{Co})$ after the Mann-Whitney test $\left(^{*}: p<0.05\right)$.

addition $\left(\mathrm{NH}_{4}^{+}+\mathrm{NO}_{3}^{-}\right)$compared to the unamended controls. This significant increase was observed irrespective of whether these $\mathrm{N}$ sources were added alone or in combination with DIP or glucose (N, NP, NC, NPC treatments, Fig. 5, $p<0.03$ ). Only PC and $\mathrm{C}$ addition on day 4 led to significant BP increase without $\mathrm{N}$ addition $(p<0.05)$ however, it increased to a much smaller extent than with all $\mathrm{N}$ combinations (factor 1.5 and 1.1, respectively). On day 20, only $\mathrm{N}$ amendments led to significant BP increases after $48 \mathrm{~h}$ incubations, compared to the unamended control (Fig. 5, $p<0.03$ ). 


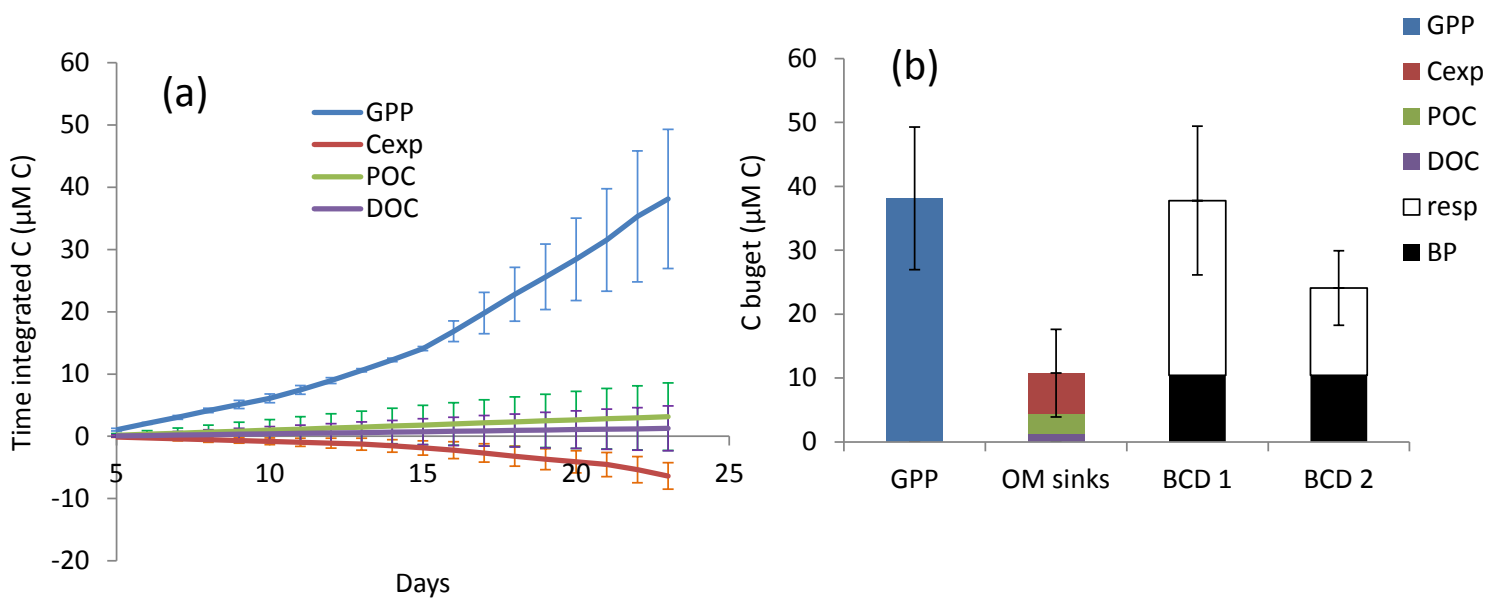

Figure 6. Carbon budget of the mesocosms with time ( $\mu \mathrm{MC}$ ). (a) Evolution of time-integrated gross primary production $(\mathrm{GPP})$, $\mathrm{C}$ export in sediment traps (Cexp); time-integrated net POC and net DOC are calculated assuming linear fits of these variables between days 5 and 23 (see Table 3). (b) Budget of time-integrated data on day 23. The difference GPP - (Cexp + net DOC + net POC) was assumed to be community respiration (resp). The range of heterotrophic bacterial carbon demand (BCD) was calculated based on two hypotheses: $\mathrm{BR}=100 \% \mathrm{CR}$ $(\mathrm{BCD} 1)$ or $\mathrm{BR}=50 \% \mathrm{CR}(\mathrm{BCD} 2)$. Standard errors are plotted from the sum of each category using propagation of errors.

\subsection{Cell-specific leucine incorporation rates}

Among the different groups sorted by flow cytometry, significant cell-specific leucine incorporation rates into macromolecules were obtained for heterotrophic bacterioplankton. LNA, HNA and hi-HNA cells had specific activities ranging from 20 to $554 \times 10^{-21}$ mole cell ${ }^{-1} \mathrm{~h}^{-1}$. Overall, cellspecific leucine incorporation rates for LNA cells were lower than rates for HNA cells (except d19), and rates for Hi-HNA cells were 1.2-4.8 times greater than rates for HNA cells (Table 3). All cell-specific rates increased when bulk activities increased. Among autotrophic groups, significant leucine incorporation was detected for Prochlorococcus cells (PRO) only on day 21 and day 23 , due to the low volume available for sorting and a significant decrease of PRO abundances in the samples to be sorted when compared to the abundances determined on samples analysed only three months after the experiment. We checked on fresh Mediterranean samples that Prochlorococcus cells were clearly detectable with the flow cytometer setting chosen so we could discard any instrument problem. We assumed that the lower detection of the PRO cells was due to the long storage period of ${ }^{3} \mathrm{H}$-leucine labelled samples until cell sorting (two years at $-80^{\circ} \mathrm{C}$ ) that could induce a loss of fluorescence or cell damages. We obtained a maximum of 1200 sorted PRO cells. Thus, even when the signal was significant, it was associated with a high standard deviation ( $40 \%$ on day 21 , Table 3). In contrast, Synechococcus cells (SYN) were easily detected and their total abundance matched with the total counts determined on samples analysed three months after the experiment. Additional 561 and $355 \mathrm{~nm}$ laser excitations allowed us to distinguish two different subgroups, not clearly distinguishable using only $488 \mathrm{~nm}$ laser excitation, separated mainly on the criterion of orange fluorescence (LO-SYN and HO-SYN; Fig. 2), suggesting different relative amounts of accessory pigments (Neveux et al., 2010). Leucine incorporation was detected in both $\mathrm{SYN}$ groups for all analysed samples. For a given sampling date, cell-specific rates of both groups were almost equal, and increased on day 21 and 23 compared to days 15 and 19. They were lower than LNA cell-specific rates (from $\sim 20 \%$ of the LNA rates at day 15 to $\sim 70 \%$ at day 21). Cell-specific rates of LO-SYN and HOSYN diverged only on day 23 (Table 3). At this date, cell specific rates for LO-SYN were twice as high as for LNA cells, reaching $131 \times 10^{-21}$ mole cell ${ }^{-1} \mathrm{~h}^{-1}$. Overall, the contribution of the two Synechococcus groups to the bulk activity was very low: it ranged from 0.2 to $0.7 \%$ for LO-SYN or HO-SYN (i.e. the contribution reached a max of $1.5 \%$ for both SYN groups together) and $0.01-0.02 \%$ for PRO (when detected), respectively. Contribution of LNA cells to the bulk activity was $4-12 \%$. Thus, the most important contribution to the bulk leucine activity was due to HNA and Hi-HNA cells.

\subsection{Carbon budget}

We used the advantage of a day-to-day sampling in an enclosed system to compute a carbon budget that will allow us to estimate the fate of phytoplankton-derived organic carbon and the metabolic balance. This carbon budget was calculated using time-integrated data and thus took into account the whole data set. First, each time point was averaged for the three sampling depths, and then time integration was calculated separately for each mesocosm assuming a linear trend between two successive days. A mesocosm average was calculated based on the time-integrated data ob- 
Table 3. Specific leucine activities of main groups sorted: PRO (Prochlorococcus), LO-SYN (low orange fluorescence Synechococcus-like cells), HO-SYN (high orange fluorescence Synechococcus-like cells, PE (autotrophic pico-eukaryotes), LNA (low nucleic acid), HNA (high nucleic acid), Hi-HNA (high size and high nucleic acid) heterotrophic bacteria and bulk activities (total community leucine incorporation rates) corresponding to the same sample. When tests of reproducibility have been done, the corresponding data are indicated with their standard deviation. bdl: below detection limits, lag: lagoon waters.

\begin{tabular}{lllllllll}
\hline & PRO & LO SYN & HO SYN & PE & LNA & HNA & Hi-HNA & Bulk \\
\hline & \multicolumn{7}{c}{$\times 10^{-21}$} & mole leu cell ${ }^{-1} \mathrm{~h}^{-1}$ \\
n15 M1 & bdl & $4.6 \pm 1.9$ & $3.5 \pm 0.3$ & $19 \pm 5$ & $20.6 \pm 0.2$ & $67 \pm 1$ & 79 & pmole leu L $\mathrm{L}^{-1} \mathrm{~h}^{-1}$ \\
d19 M1 & bdl & 5.4 & 3.5 & 17 & 27 & 16 & 80 & $126 \pm 3$ \\
d21 lag & $69 \pm 28$ & $30 \pm 4$ & $25 \pm 4$ & $79 \pm 12$ & 39 & 214 & 554 & $186 \pm 6$ \\
d23 M3 & 22 & 131 & 42 & 108 & 56 & 113 & 356 & $242 \pm 7$ \\
\hline
\end{tabular}

tained in each of the three mesocosms, with error bars representing the standard deviation (SD) among the three mesocosms (Fig. 6a). Gross primary production (GPP) is derived from $\mathrm{PP}$ assuming GPP $=\mathrm{PP} \times 1.72$ (Moutin et al., 1999) and represents the whole photosynthetic source of organic matter, including both particulate and extracellular release forms. The cumulated GPP at day 23 was $38 \pm 11 \mu \mathrm{MC}$ (Fig. 6b). Carbon exported by sedimentation into the traps (Cexp) was corrected in $\mu \mathrm{M} \mathrm{C}$ units based on a mean constant water volume inside M1, M2 and M3 (see Berthelot et al., 2015 for details) and its cumulated value reached $6.4 \pm 2.1 \mu \mathrm{MC}$ on day 23. For POC and DOC, for which data were more irregular and showed outliers, we decided to calculate net variations of POC and DOC after a linear fit of the discrete data set between days 5 and 23 in each mesocosm (Table 4). POC increased linearly in M1 and M3 (0.12 and $0.48 \mu$ mole $\mathrm{CL}^{-1} \mathrm{~d}^{-1}, r=0.32 p<0.03$ and $r=0.70 p<0.001$, respectively) and showed no trend in M2. A significant increase of DOC was only observed in M2 (Table 4). Due to the high SD resulting from variability in net variation of POC and DOC vs. time between the three mesocosms, the average accumulation of DOC and POC estimated for the carbon budget was negligible (Fig. 6a), and the most important measured fate of GPP was Cexp, representing $17 \%$ of GPP (Fig. 6b). GPP - (net DOC + net POC + Cexp) can be considered as community respiration (CR). CR was calculated and reached $27 \pm 11 \mu \mathrm{M}$ cumulated from day 5 to 23 , i.e. $71 \%$ of GPP.

\section{Discussion}

\subsection{Variability within the triplicate mesocosms}

Overall, M3 exhibited maximum peaks of chlorophyll biomass as well as PP and BP rates, and these different responses were particularly seen during P2. A time lag of a few days in the succession of the different planktonic populations was noticed, particularly for nitrogen fixers (Turk-Kubo et al., 2016), and DIP was consumed more rapidly in M1. However, slight divergence in biological and chemical evo- lution among different replicated mesocosms is not uncommon, particularly after the first week of enclosure (MartínezMartínez et al., 2006; Pulido-Villena et al., 2014). Here, the divergence probably resulted from a combination of bottomup (availability of DIP and nitrogen) and top-down controls (grazing pressure and viral lysis). The initial conditions prevailing before the DIP enrichment could occur also at the origin of the divergence. Indeed mesocosms were closed three days before the DIP addition, and many species of diazotrophs exhibit a patchy distribution (Bombar et al., 2015). In addition, Hunt et al. (2016) noticed larger amount of zooplankton individuals in M3 at the beginning of the experiment, some of which, stressed by the mesocosms, might have died (some larger amounts of "swimmers" were recovered in the traps in M3), contributing to supplementary sources of $\mathrm{N}$ in $\mathrm{M} 3$. Nevertheless, overall the replicability among mesocosms was considered sufficiently correct for most of the biogeochemical stocks, fluxes and abundances of phytoplankton groups (Bonnet et al., 2016b) and thus our results are discussed based on averages.

\subsection{N limitation and coupling between $\mathrm{BP}$ and $\mathrm{N}_{2}$ fixation}

BP was significantly enhanced on a short-term scale (1-2 days) by $\mathrm{NO}_{3}^{-}+\mathrm{NH}_{4}^{+}$but not by DIP or glucose amendments, indicating that BP was directly N-limited and/or indirectly after stimulation of $\mathrm{N}$-limited phytoplankton (Fig. 4). In the New Caledonia lagoon, N-limitation has previously been suggested, based on a 1-year survey of nutrient ratios (Torréton et al., 2010). N-limitation is a recurrent feature observed in the ultra-oligotrophic south-eastern Pacific Gyre (Van Wambeke et al., 2008a; Halm et al., 2012), as assessed from short-term (1-3 days) enrichment experiments or incubations. As $\mathrm{N}_{2}$ fixation is assumed to be the only process providing a source of new nitrogen to the mesocosms in this experiment, we examined the potential links between $\mathrm{N}_{2}$ fixation rates and BP. First, marine heterotrophic diazotrophs were detected at low abundances during the mesocosms experiment: $\gamma$-24774A11 with 
Table 4. Linear regression fits on temporal trends of POC and DOC in M1, M2 and M3 from days 5 to 23. DOC has been sampled only at $6 \mathrm{~m}$ depth in the three mesocosms. df: degree of freedom, $r$ : Pearson correlation coefficient, $p$ : probability, ns: not significant. For POC trend, some outliers have been suppressed from the regressions.

\begin{tabular}{lllllll}
\hline & Range $\mu \mathrm{M}$ & Outliers $\mu \mathrm{M}$ & slope & df & $r$ & $p$ \\
\hline POC M1 & $4.7-12.4$ & 19.3 & 0.12 & 35 & 0.32 & 0.02 \\
POC M2 & $7.1-11.6$ & $15.0,15.0,17.3$ & -0.009 & 28 & 0.03 & ns \\
POC M3 & $6.5-18.9$ & no & 0,47 & 36 & 0.70 & $<0.001$ \\
\hline DOC M1 & $54-64$ & no & 0.071 & 13 & 0.15 & ns \\
DOC M2 & $53-62$ & no & 0.25 & 13 & 0.48 & 0.04 \\
DOC M3 & $54-66$ & no & -0.12 & 14 & 0.22 & ns \\
\hline
\end{tabular}

ca. $10^{2}-10^{3}$ nifH gene copies $\mathrm{L}^{-1}$ (Turk-Kubo et al., 2015), and 16S tags corresponding to heterotrophic diazotrophs like Bradyrhizobium or Mesorhizobium were scarce (Pfreundt et al., 2016b). Therefore, $\mathrm{N}_{2}$ fixation directly performed by heterotrophic bacteria probably accounted for a minor fraction of bulk $\mathrm{N}_{2}$ fixation during the mesocosm experiment. Second, as the log-log relationship between $\mathrm{N}_{2}$ fixation rates and bacterial production was not significant during $\mathrm{P} 1$, and only slightly significant during $\mathrm{P} 2(r=0.21$, $p=0.04$ ), the excretion of DON (dissolved organic nitrogen) and $\mathrm{NH}_{4}^{+}$by diazotrophs likely did not supply much nitrogen for heterotrophic prokaryotes directly, particularly during P1 when the main organisms responsible for diazotrophy were diatom-symbiotic (Turk-Kubo et al., 2015). Assuming a C / N molar ratio of around 6.8 for heterotrophic prokaryotic biomass (Fukuda et al., 1998), $\mathrm{N}_{2}$ fixation might have provided 17 to $30 \%$ of the nitrogen demand of heterotrophic prokaryotes, depending on the phase and the mesocosm considered (Table 1). This proportion increases to $30-37 \%$ if we consider a $\mathrm{C} / \mathrm{N}$ ratio of 8.2 , which seems more appropriate in the Pacific Ocean (Fukuda et al., 1998). Thus, $\mathrm{N}_{2}$ fixation contributed to, but was not sufficient to sustain, $100 \%$ of the $\mathrm{N}$ requirements of heterotrophic bacteria during this study. Other potential sources were initial DON stocks, concentrations of which decreased slightly at the end of the experiment (Berthelot et al., 2015) and detritus. Indeed, there was a decay of larger phytoplankton cells after the closure of the mesocosms as discussed by Knapp et al. (2015) and Leblanc et al. (2016) following DIP availability (TDIP) as well as decreases in PP (Berthelot et al., 2015) and Synechococcus 16S tags dropped substantially between days 2 and 4 (Pfreundt et al., 2016b). Such detritus probably also contributed to sustain BP. NanoSIMS analyses were performed during a parallel experiment done at the height of a bloom of diazotrophic Cyanothece-like cyanobacteria (UCYN-C) on days 17-20 in M2 (Bonnet et al., 2016a). After $24 \mathrm{~h}$ of ${ }^{15} \mathrm{~N}_{2}$-incubations, these authors reported significant ${ }^{15} \mathrm{~N}$-enrichment in picoplanktonic cells $(0.2-2 \mu \mathrm{m}$ fraction). This confirmed a rapid (one day) transfer of DDN (also ${ }^{15} \mathrm{~N}$-enriched) to picophytoplankton, and potentially heterotrophic bacteria. However, such transfer likely occurred indirectly through DON after mortality and grazing processes, as shown by model simulations run during the VAHINE project (Gimenez et al., 2016).

\subsection{Alkaline phosphatase activity and $P$ acquisition}

A slight $T_{\text {DIP }}$ decrease was noticed in the mesocosms before the DIP spike but not in the lagoon, suggesting a lower $\mathrm{P}$ availability inside and not outside the mesocosms. Therefore, $\mathrm{N}_{2}$ fixers might benefit from continuous and variable inputs of DIP sources in the lagoon waters during that period. This is also confirmed by the low values of alkaline phosphatase activity in the lagoon at the start of the experiment. Whether these sources were coming from the benthos (Torréton et al., 2002), the atmosphere (soot emission can influence lagoon waters inside and outside the barrier reef, Mari et al., 2014) and/or currents (Fichez et al., 2010) is beyond the scope of this study. Inside the mesocosms, when the added DIP was consumed, the observed increase of APA could be due to (i) a population switch towards phosphatase producers, which can be heterotrophic bacteria and phytoplankton, and (ii) increases in specific activities due to enzymatic induction or (iii) both. We used POP as a proxy of living biomass (Duhamel et al., 2007) to estimate specific activities (nmole MUF-P hydrolyzed per unit POP per unit time) and found the same trend for specific activities and for bulk APA (i.e. specific activity increased up to 10-fold). APA was produced by different phylogenetic groups of heterotrophic bacteria, but also by cyanobacteria, as shown on a metatranscriptomic study in the special issue (Pfreundt et al., 2016a), with the highest levels of alkaline phosphatase transcripts originating from Synechococcus on days 14 and 20. Our results and those of Pfreundt et al. (2016a) suggested a switch towards a microbial population that produced phosphatase to escape $\mathrm{P}$ depletion after a transient Preplete period. Although $T_{\mathrm{DIP}}$ decreased and APA increased up to values analogous to those observed in P-limited areas (Moutin et al., 2002; Van Wambeke et al., 2002, respectively), heterotrophic bacteria stayed continuously $\mathrm{N}$-limited but not P-limited. As discussed in Pfreundt et al. (2016a, b), some acquisition mechanisms of large P-containing organic 
molecules and reduction of cellular $\mathrm{P}$ quota also helped microbial communities to resist $\mathrm{P}$ depletion during $\mathrm{P} 2$ phase.

\subsection{Cyanobacterial assimilation of leucine}

BP was used in this study as a strict proxy of heterotrophic bacterial production. As we incubated ${ }^{3} \mathrm{H}$ leucine under light conditions, we could not exclude the hypothesis that photoheterotrophic activity and the possibility that some photosynthetic cyanobacteria incorporate leucine could biases BP estimates. Whether light stimulation of bacterial production can be explained by direct effects (assimilation or organic molecules by autotrophs), indirect effects (stimulation of BP through release of organic molecules or photolabilization of organic matter) or both is difficult to determine (Béjà and Suzuki, 2008). Assimilation of methionine, leucine and ATP was shown to be enhanced under light-incubation conditions in the North and South Atlantic oceans and these increases are generally attributed to stimulation of Prochlorococcus and SAR11 (Evans et al., 2015), but the spectrum of organic molecules tested is low. In the New Caledonia lagoon, incubation of samples under different light regimes influences estimates of BP determined by the thymidine technique (Rochelle-Newall et al., 2008), but so far there is no information available on the light effect on leucine uptake around New Caledonia. The capacity of both marine Prochlorococcus and Synechococcus to assimilate some organic molecules is evident from culture studies, as well as flow-cytometry cell-sorting and gene studies (Béjà and Suzuki, 2008). Assimilation of leucine by cyanobacteria can also occur in the dark (Talarmin et al., 2011), but light clearly favours assimilation of leucine by cyanobacteria (Mary et al., 2008b). The polypropylene tubes used in this study to incubate BP attenuated the light intensity by $40 \%$ without spectral distortion in the visible range (Richardson and Porter, 2005). Under such conditions, which were intermediary between simulated in situ light conditions and dark conditions, significant incorporation of leucine into macromolecules was seen by flowcytometry sorting of Synechococcus cells. We could not unambiguously verify leucine incorporation into Prochlorococcus cells due to technical reasons (low volumes and long storage limitations). To conclude, although the relative contribution of cyanobacteria (PRO + SYN) to the bulk (community) leucine assimilation into proteins was less than $2 \%$ and could not be responsible for a bias in BP estimates, we estimate significant potential for leucine to be assimilated by cyanobacteria. Note that we used a $10 \mathrm{nM}$ leucine concentration for cell sorting, but in situ natural concentrations could be much lower. More studies are needed, investigating the potential use of other organic molecules in lower, close to in situ concentrations. Mixotrophy may be the rule rather the exception in these experimental systems (Moore, 2013; Evans et al., 2015).

\subsection{Phytoplankton-bacteria coupling and metabolic balance}

Torréton et al. (2010) report mean Chl concentration around $0.3 \mu \mathrm{g} \mathrm{L}^{-1}$ over a seasonal cycle performed at an oligotrophic station in the New Caledonia lagoon. These concentrations are close to our reference conditions outside the mesocosms (lagoon waters), where means of $\mathrm{Chl}$ values were 0.21 and $0.30 \mu \mathrm{g} \mathrm{L}^{-1}$ during $\mathrm{P} 1$ and $\mathrm{P} 2$ phases. Under these oligotrophic conditions, the seasonal variability of $\mathrm{BP}$ and $\mathrm{PP}$ in the Nouméa lagoon is much lower than in temperate waters, only about 3-fold with an average BP / PP ratio of 0.21 and some rare peaks reaching 0.6 (Torréton et al., 2010). This is in accordance with the range of $\mathrm{BP} / \mathrm{PP}$ ratios encountered in the lagoon waters during our study, with average values ranging 0.33 to 0.39 during phases $\mathrm{P} 1$ and $\mathrm{P} 2$, respectively. On the contrary, inside the mesocosms, average BP / PP ratios were generally higher than in the lagoon waters whatever the phase or the mesocosm considered. A negative trend of BP / PP with increasing PP was obtained, suggesting that a larger fraction of PP is channelled through the microbial food web when PP decreases, as observed in the oligotrophic Mediterranean Sea (Conan et al., 1999). This is also the trend when considering a large oceanic data set examined by Fouilland and Mostajir (2010). Indeed in their study, regression of $\log (\mathrm{BP})$ as a function of $\log (\mathrm{PP})$ resulted in a slope of 0.57 , inferring that $\mathrm{BP}$ increases less rapidly than $\mathrm{PP}$ when $\mathrm{PP}$ increases. Contrary to the weakness (during $\mathrm{P} 2$ ) or absence of (during P1) correlation between $\mathrm{BP}$ and $\mathrm{N}_{2}$ fixation rates described above, strong relationships between BP and Chl, and between BP and PP were obtained during both phases (Fig. 4). This suggests that $\mathrm{N}_{2}$ fixation stimulated autotrophic communities during the VAHINE experiment, which may in turn have produced organic matter for heterotrophic prokaryotes. BP and PP are determined routinely, but to estimate the flux of PP channelled through heterotrophic bacteria or to infer metabolic balance between autotrophy and heterotrophy, bacterial carbon demand (BCD) and gross primary production (GPP) must be also estimated. Such carbon fluxes are not directly estimated but are derived from PP and BP using additional measurements of bacterial growth efficiency (or bacterial respiration) and phytoplankton extracellular release of DOC. These parameters are less frequently acquired due to time-consuming and difficult technologies (del Giorgio and Cole, 1998; Nagata, 2000), which led to controversy on the metabolic balance in oligotrophic environments (Cole et al., 1988; Ducklow et al., 2002; Van Wambeke et al., 2008b; Fouilland and Mostajir, 2010; Moran and AlonsoSaez, 2011). BCD is derived from BP by the use of bacterial growth efficiency (BGE) or respiration rates which are not often measured concomitantly with $\mathrm{PP}$ and $\mathrm{BP}$, and in many oligotrophic environments BCD / PP is higher than 1, or respiration exceeds PP (del Giorgio et al., 1997). To explain this, different arguments are generally proposed. First, other DOM sources than those deriving from phytoplankton 
(allochthonous sources) are used to sustain BCD. In Pacific lagoons, excretion of mucus by coral has been proposed as a supplementary source of DOM for heterotrophic bacterioplankton (Torréton et al., 2002; Wild et al., 2004). Second, phasing between BP and PP peaks during seasonal blooms and occasional presence of PP bursts (see for example Steinberg et al., 2001) are not always detected due to inappropriate sampling frequency for BP and PP measurements. Daily and parallel measurements of both BP and PP in the mesocosms avoided such problems in this study.

Assuming negligible effect of a biofilm development on the mesocosms walls (Knapp et al., 2015) on the plankton $\mathrm{C}$ budget, the main fate of photosynthetically fixed organic carbon during the experiment was respiration (71\% of GPP) then sedimentation (17\% of GPP). The different responses between the triplicate mesocosms led to a great propagation of errors and thus the variability of CR / GPP ratio was also high $(70 \pm 36 \%)$. CR being lower than GPP, the biological system inside mesocosms was net autotrophic, with an upper error limit close to metabolic balance between autotrophy and heterotrophy.

In the lagoon, close to Grande Rade Bay, long residence times favoured local degradation, refractorization of organic matter and not sedimentation (Mari et al., 2007). However, as these authors discussed, modification of phytoplankton community composition in Grande Rade Bay and the presence of metals could influence sticking properties of polymers. The confinement of the seawater inside the mesocosms probably favoured to some extent the accumulation of UCYNaggregates, as well as a possible reduction of grazing pressure (by a factor of 1.6) in the mesocosms compared to those in the lagoon waters (Turk-Kubo et al., 2015; Bonnet et al., 2016a; Hunt et al., 2016). However, UCYN-C formed large aggregates $(100-500 \mu \mathrm{m})$ embedded in an organic matrix that included TEP, which were largely responsible for enhanced export flux through sedimentation observed during P2 (Berthelot et al., 2015; Berman-Frank et al., 2016; Knapp et al., 2015). TEP evolution with time, however, and the TEP-C to TOC ratio were similar in the lagoon waters, where wave turbulence and tidal effects were present, and in the enclosed mesocosms, where these hydrodynamics were reduced and concentrations were similar (Berman-Frank et al., 2016). In an unconstrained ordination analysis, Pfreundt et al. (2016b) described significant differences in bacterial communities between M1 and the lagoon, but similar temporal dynamics. Direct comparisons of our export results with findings from open ocean studies should be made cautiously as our mesocosms were both shallower $(15 \mathrm{~m})$ than in typical oceanic export studies $(>100 \mathrm{~m})$ and exhibited reduced turbulence.

In order to calculate the fraction of GPP that directly or indirectly channelled through the microbial food web, the bacterial carbon demand (BCD) must be estimated through additional estimates of bacterial respiration (BR) or bacterial growth efficiency (BGE). In an oligotrophic site inside the Nouméa lagoon, BGE was estimated at $10 \%$ using incubated samples where oxygen changes were followed with time in the dark (Briand et al., 2004). However, as suggested by Aranguren-Gassis et al. (2012), using consistently low BGE, derived from size fractionation experiments and longduration incubations, leads to probable BGE underestimation. In the lagoon, the use of a $10 \%$ BGE would lead to BCD values higher than GPP (Rochelle-Newall et al., 2008). If we assume such low BGE in the mesocosms (10\%), cumulated $\mathrm{BR}$ from day 5 to 23 would rise to $93 \pm 6 \mu \mathrm{MC}$, which is not realistic compared to $\mathrm{CR}$ estimated from the carbon budget. A more appropriate BGE of $27 \pm 9$ to $43 \pm 11 \%$ could be calculated, based on minimum and maximum ranges admitted for BR / CR ratio (from 100 to $50 \%$, Lemée et al., 2002), and based on propagation of errors due to the variability within triplicate mesocosms (Table S1 in the Supplement). For sensitivity analysis of BR and BGE calculation from the carbon budget, we examined whether the errors of different methodological assumptions (conversion factors, analytical errors) were higher than those arising from variability between triplicate mesocosms. We considered different errors based on literature data for all the parameters used in computation of BR and BGE (i.e. GPP, Cexp, DOC, POC and BP). For GPP, we assumed GPP $=1.72 \times$ PP, i.e. PP / GPP ratio $=58 \%$. In the South Pacific Ocean, the mean average PP to GPP ratio (based on comparison between oxygen and ${ }^{14} \mathrm{C}$ technique) was $47 \%$ (Van Wambeke et al., 2008b). If we consider that the sum of dissolved and particulate PP in the lagoon $\left({ }^{14} \mathrm{C}\right.$ technique, Rochelle-Newall et al., 2008) is a good proxy of GPP, then an upper limit for this ratio is $65 \%$ in the lagoon. We thus applied a $15 \%$ variability to the $\mathrm{PP} / \mathrm{GPP}$ ratio, leading to $\mathrm{GPP}=1.36 \times \mathrm{PP}$ to $2.32 \times \mathrm{PP}$, i.e. approximately a $30 \%$ variability on the conversion factor. For BP, we assumed a $25 \%$ daily variability of BP (Church et al., 2006; Van Wambeke et al., 2008c; Torréton et al., 2010). For Cexp, DOC and POC, we assumed analytical errors of $10 \%$. We then used propagation of errors to compute the error associated with BR and BGE (Table S1). For GPP, the errors resulting from triplicate mesocosms or resulting from conversion factor and analytical errors were the same. According to the propagation of errors, the error associated with GPP has the largest effect on estimates of BR. The uncertainty of DOC, POC and Cexp arising from variability within the triplicate mesocosms is higher than the methodological error, whereas it is the opposite for BP. Overall, the uncertainty of BGE estimates arising from variability within triplicate mesocosms or methodology is similar $(27 \pm 9$ or $27 \pm 10 \%$ for BGE based on BR $=\mathrm{CR}, 43 \pm 11$ or $43 \pm 12 \%$ for $\mathrm{BGE}$ based on $\mathrm{BR}=\mathrm{CR} / 2$ )

The BGE values determined from $\mathrm{C}$ budget could be potentially related to a beneficial effect of photoheterotrophy. Indeed, in a companion metatranscriptomic study performed in M1 (Pfreundt et al., 2016a), accumulation of proteorhodopsin transcripts was recurrently detected among varying groups of bacteria notably Pelagibacteraceae and SAR86 
These groups, belonging to the alpha- and gammaproteobacteria, respectively, were also abundant community members as observed through $16 \mathrm{~S}$ sequencing (Pfreundt et al., 2016b). Aerobic anoxygenic phototrophic (AAP) bacterial abundances are reported to be particularly abundant in the South Pacific Ocean (Lami et al. 2007), but to date, AAP abundances are not available in the lagoon and they were not counted in this experiment. Nevertheless, Pfreundt et al. (2016a) detected expression of the pufM gene, encoding a photoreaction centre protein of AAP bacteria. Transcript abundances were an order of magnitude lower than for proteorhodopsin and only observed for a group of Rhodocyclaceae on day 14 but were much weaker for Rhodobacteraceae on day 18. This suggests that AAP bacteria did not play a major role in the investigated system and did not influence the above calculation to a large extent. Dokdonia sp. strain MED134, a proteorhodopsin-containing flavobacteria, was shown to increase the maximum number of cells reached when growing in light compared to darkness. However, if DOM was added initially, light vs. dark responses changed depending on DOM concentrations (Gomez-Consarnau et al., 2007). Other laboratory experiments, in contrast, showed no difference in growth rates or maximum cell yields of Pelagibacter ubique cultures grown in natural seawater (in a diurnal light regime or in complete darkness; Giovannoni et al., 2005). The BGE of a bacteriochlorophyll-containing strain (Erythrobacter sp.) was shown to increase during light periods in a continuous culture (Hauruseau and Kobližek, 2012). Thus the energy benefits of photoheterotrophy remain controversial and are related to the difficulty of having true oligotrophic conditions in pure culture. Based on an energy budget, Kirchman and Hanson (2013) suggested that the net energy gained by light is mostly sufficient to meet maintenance cost of AAP but is not enough to meet that of proteorhodopsin-based photoheterotrophic bacteria. Heterotrophic bacteria are limited by $\mathrm{N}$ but also by energy in the South Pacific (Van Wambeke et al. 2008a); this could give an advantage to photoheterotrophic prokaryotes for growth and their success in this area.

Assuming BGE values ranging from 27 to $43 \%$, the BCD / GPP ratio would range from 63 to $99 \%$. A large part of the GPP is thus channelled through the microbial food web pathway within 20 days. To examine potential links between phytoplankton release and BP, we estimated a extracellular release of $35 \%$, as determined previously inside the Nouméa lagoon (Rochelle-Newall et al., 2008). Such values are in agreement with a higher percent of extracellular release that is generally obtained in nutrient-limited environments (Nagata, 2000). According to Rochelle-Newall et al. (2008), contemporaneous DOC excreted by phytoplankton was sufficient to meet BCD only in the coastal part of the lagoon, but not in the offshore oligotrophic part of the lagoon where the VAHINE experiment was performed, but these authors used a $10 \%$ BGE. In the mesocosms, still based on an extracellular release representing $35 \%$ of GPP, DOC release was esti- mated at $13 \mu \mathrm{MC}$ produced between 5 and 23 days. This is not sufficient to satisfy BCD cumulated for the same period (calculated as $24-38 \mu \mathrm{M} \mathrm{C}$ ), although we used BGE varying from 27 to $43 \%$ as discussed above. Thus, heterotrophic bacteria in the mesocosms used additional, not contemporaneous, sources of organic matter derived from phytoplankton after transformation through the food web like enzymatic hydrolysis of detritus, viral lysis and/or sloppy feeding.

\section{Conclusions}

This study confirms that in the Nouméa lagoon, $\mathrm{N}_{2}$ fixation is a relevant process for fuelling the microbial food web and sustaining a biological system which is net autotrophic or close to metabolic balance. The relatively high BGE computed from the carbon budget (27-43\%) could be related to light-harvesting systems developed by abundant bacterial photoheterotrophs. The success of Synechococcus over Prochlorococcus described in companion papers (Leblanc et al., 2016; Pfreundt et al., 2016b) might be attributed to their ability to assimilate leucine and possibly other amino acids, as well as reduction of their cellular P demand through sulfolipid synthesis. The relative importance of mixotrophy in these oligotrophic system implies that it is important to (i) find alternative techniques to dark incubations to estimate bacterioplankton respiration, similarly to continuous measurements with oxygen microprobes during alternate light and dark periods (Pringault et al., 2007) and (ii) to detect organisms responsible for the assimilation of a wide variety of organic molecules by cell sorting. From the carbon budget, a BCD to GPP ratio was estimated to range between 63 and $100 \%$; thus a large part of the primary production is channelled through the microbial food web. Bacterial production was strongly coupled with Chl biomass and/or PP, rather than with $\mathrm{N}_{2}$ fixation rates, suggesting that indirect routes through lysis, grazing and mortality of phytoplankton were substantial for providing labile organic matter for heterotrophic bacteria.

\section{The Supplement related to this article is available online at doi:10.5194/bg-13-3187-2016-supplement.}

Author contributions. Sophie Bonnet was the chief scientist responsible for the VAHINE programme. She designed and executed the experiment in mesocosms. France Van Wambeke sampled for and analysed BP and APA, Thierry Moutin sampled for and analysed $T_{\text {DIP }}$ and PP, Aude Barani performed the cell sorting, wrote the corresponding M\&M section and made Fig. 2, Hugo Berthelot contributed to the analyses of bacterial abundances by flow cytometry, Martine Rodier sampled for and analysed Chl data; France Van Wambeke and Ulrike Pfreundt equally wrote the manuscript and made the other figures. All the authors reviewed the manuscript. 
Acknowledgements. Funding for this research was provided by the Agence Nationale de la Recherche (ANR starting grant VAHINE ANR-13-JS06-0002), INSU-LEFE-CYBER programme, GOPS, IRD and M.I.O. The participation of UP and WRH was supported by the German-Israeli Research Foundation (GIF), project number 1133-13.8/2011 and the MiSeq-based microbial community analysis by the EU project MaCuMBA (Marine Microorganisms: Cultivation Methods for Improving their Biotechnological Applications; grant agreement no: 311975) to WRH. The authors thank the captain and crew of the R/V Alis. We acknowledge the SEOH divers service from the IRD research centre of Nouméa (E. Folcher, B. Bourgeois and A. Renaud) and from the Observatoire Océanologique de Villefranche-sur-mer (OOV, J. M. Grisoni) as well as the technical service of the IRD research centre of Nouméa for their helpful technical support. C. Guieu, F. Louis and J. M. Grisoni from OOV are warmly thanked for the mesocosms design and their useful advice for deployment. We are grateful to the Regional Flow Cytometry Platform for Microbiology (PRECYM) of the Mediterranean Institute of Oceanography (MIO) for the flow-cytometry analyses. We acknowledge Anne Desnues for help in sampling, Karine Leblanc, Bruno Charrière, Jules Héliou for analysing TOC, POC and Chl data and four referees which helped to improve the manuscript.

Edited by: F. Lacan

\section{References}

Aranguren-Gassis, M., Teira, E., Serret, P., Martínez-García, M., and Fernández, E.: Potential overestimation of bacterial respiration rates in oligotrophic plankton communities, Mar. Ecol.Prog. Ser., 453, 1-10, 2012.

Béjà, O. and Suzuki, M.: Photoheterotrophic marine prokaryotes, in: Microbial Ecology of the Oceans, Second Edn., edited by: Kirchman, D., John Wiley \& Sons, New York, 131-157, 2008.

Berman-Frank, I., Spungin, D., Rahav, E., Van Wambeke, F., TurkKubo, K., and Moutin, T.: Dynamics of transparent exopolymer particles (TEP) during the VAHINE mesocosm experiment in the New Caledonia lagoon, Biogeosciences Discuss., doi:10.5194/bg-2015-612, in review, 2016.

Berthelot, H., Moutin, T., L'Helguen, S., Leblanc, K., Hélias, S., Grosso, O., Leblond, N., Charrière, B., and Bonnet, S.: Dinitrogen fixation and dissolved organic nitrogen fueled primary production and particulate export during the VAHINE mesocosm experiment (New Caledonia lagoon), Biogeosciences, 12, 40994112, doi:10.5194/bg-12-4099-2015, 2015.

Biegala, I. and Raimbault, P.: High abundance of diazotrophic pico-cyanobacteria $(<3 \mu \mathrm{m})$ in a south-west Pacific coral lagoon, Aquat. Microb. Ecol., 51, 45-53, 2008.

Bombar, D., Taylor, C. D., Wilson, S. T., Robidart, J. C., Rabines, A., Turk-Kubo, K. A., Kemp, J. N., Karl, D. M., and Zehr, J. P.: Measurements of nitrogen fixation in the oligotrophic North Pacific Subtropical Gyre using a free-drifting submersible incubation device, J. Plankton Res., 37, 727-739, 2015.

Bonnet, S., Guieu, C., Bruyant, F., Prášil, O., Van Wambeke, F., Raimbault, P., Moutin, T., Grob, C., Gorbunov, M. Y., Zehr, J. P., Masquelier, S. M., Garczarek, L., and Claustre, H.: Nutrient limitation of primary productivity in the South- east Pacific (BIOSOPE cruise), Biogeosciences, 5, 215-225, doi:10.5194/bg-5-215-2008, 2008.

Bonnet, S., Rodier, M., Turk-Kubo, K., Germineaud, C., Menkes, C., Ganachaud, A., Cravatte, S., Raimbault, P., Campbell, E., Quéroué, F., Sarthou, G., Desnues, A., Maes, C., and Eldin, G.: Contrasted geographical distribution of $\mathrm{N}_{2}$ fixation rates and nifH phylotypes in the Coral and Solomon Seas (South-Western Pacific) during austral winter conditions, Global Biogeochem. Cy., 29, 1874-1892, doi:10.1002/2015GB005117, 2015.

Bonnet, S., Berthelot, H., Turk-Kubo, K., Fawcett, S., Rahav, E., L'Helguen, S., and Berman-Frank, I.: Dynamics of $\mathrm{N}_{2}$ fixation and fate of diazotroph-derived nitrogen in a low-nutrient, low-chlorophyll ecosystem: results from the VAHINE mesocosm experiment (New Caledonia), Biogeosciences, 13, 2653-2673, doi:10.5194/bg-13-2653-2016, 2016 a.

Bonnet, S., Moutin, T., Rodier, M., Grisoni, J.-M., Louis, F., Folcher, E., Bourgeois, B., Boré, J.-M., and Renaud, A.: Introduction to the project VAHINE: VAriability of vertical and tropHIc transfer of diazotroph derived $\mathrm{N}$ in the south wEst Pacific, Biogeosciences, 13, 2803-2814, doi:10.5194/bg-13-28032016, 2016 b.

Briand, E., Pringault, O., Jacquet, S., and Torréton, J.-P.: The use of oxygen microprobes to measure bacterial respiration for determining bacterioplankton efficiency, Limnol. Oceanogr.-Meth., 2, 406-416, 2004.

Cole, J. J., Findlay, S., and Pace, M. L.: Bacterial production in fresh and saltwater ecosystems : a cross - system overview, Mar. Ecol.-Prog. Ser., 43, 1-10, 1988.

Conan, P., Turley, C., Stutt, E., Pujo-Pay, M., and Van Wambeke, F.: Relationship between phytoplankton efficiency and the proportion of bacterial production to primary production in the Mediterranean Sea, Aquat. Microb. Ecol., 17, 131-144, 1999.

Church, M. J., Ducklow, H. W., Letelier, R. M., and Karl, D. M.: Temporal and vertical dynamics in picoplankton photoheterotrophic production in the subtropical North Pacific Ocean, Aquat. Microb. Ecol., 45, 41-53, 2006.

del Giorgio, P. A. and Cole, J. J.: Bacterial growth efficiency in natural aquatic systems, Annu. Rev. Ecol. Syst., 29, 503-541, 1998.

del Giorgio, P., Cole, J. J., and Cimbleris, A.: Respiration rates in bacteria exceeds phytoplankton production in unproductive aquatic systems, Nature, 385, 148-151, 1997.

Ducklow, H. W., Kirchman, D. L., and Anderson, T. R.: The magnitude of spring bacterial production in the North Atlantic Ocean, Limnol. Oceanogr., 47, 1684-1693, 2002.

Duhamel, S., Moutin, T., Van Wambeke, F., Van Mooy, B., Rimmelin, P., Raimbault, P., and Claustre, H.: Growth and specific Puptake rates of bacterial and phytoplanktonic communities in the Southeast Pacific (BIOSOPE cruise), Biogeosciences, 4, 941956, doi:10.5194/bg-4-941-2007, 2007.

Evans, C., Gómez-Pereira, P. R., Martin, A. P., Scanlan, D., and Zubkov, M. V.: Photoheterotrophy of bacterioplankton is ubiquitous in the surface oligotrophic ocean, Prog. Oceanogr., 135, 139-145, 2015.

Fichez, R., Chifflet, S., Douillet, P., Gérard, P., Gutierrez, F., Jouon, A., Ouillon, S., and Grenz, C.: Biogeochemical typology and temporal variability of lagoon waters in a coral reef ecosystem subject to terrigeneous and anthropogenic inputs (New Caledonia), Mar. Pollut. Bull., 61, 309-322, 2010. 
Fouilland, E. and Mostajir, B.: Revisited phytoplanktonic carbon dependencyof heterotrophic bacteria infreshwaters, transitional, coastal and oceanic waters, FEMS Microbiol. Ecol., 73, 419429, 2010.

Fukuda, R., Ogawa, H., Nagata, T., and Koike, I.: Direct determination of carbon and nitrogen contents of natural bacterial assemblages in marine environments, Appl. Environ. Microb., 64, 3352-3358, 1998.

Garcia, N., Raimbault, P., and Sandroni, V.: Seasonal nitrogen fixation and primary production in the Southwest Pacific: nanoplankton diazotrophy and transfer of nitrogen to picoplankton organisms, Mar. Ecol.-Prog. Ser., 343, 25-33, 2007.

Gimenez, A., Baklouti, M., Bonnet, S., and Moutin, T.: Biogeochemical fluxes and fate of diazotroph derived nitrogen in the food web after a phosphate enrichment: Modeling of the VAHINE mesocosms experiment, Biogeosciences Discuss., doi:10.5194/bg-2015-611, in review, 2016.

Giovannoni, S. J., Bibbs, L., Cho, J. C., Stapels, M. D., Desiderio, R., Vergin, K. L., Michael S. Rappe, M. S., Laney, S., Wilhelm, L. J., Tripp, H. J., Mathur, E. J., and Barofsky, D. F.: Proteorhodopsin in the ubiquitous marine bacterium SAR11, Nature, 438, 82-85, 2005.

Gomez-Consarnau, L., Gonzalez, J. M., Coll-Llado, M., Gourdon, P., Pascher, T., Richard Neutze, R., Carlos Pedros-Alio, C., and Pinhassi, J.: Light stimulates growth of proteorhodopsin containing marine Flavobacteria, Nature Letters, 445, 210-213, 2007.

Guieu, C., Dulac, F., Desboeufs, K., Wagener, T., Pulido-Villena, E., Grisoni, J.-M., Louis, F., Ridame, C., Blain, S., Brunet, C., Bon Nguyen, E., Tran, S., Labiadh, M., and Dominici, J.-M.: Large clean mesocosms and simulated dust deposition: a new methodology to investigate responses of marine oligotrophic ecosystems to atmospheric inputs, Biogeosciences, 7, 27652784, doi:10.5194/bg-7-2765-2010, 2010.

Halm, H., Lam, P., Ferdelman, T. G., Lavik, G., Dittmar, T., LaRoche, J., D'Hondt, S., and Kuypers, M.: Heterotrophic organisms dominate nitrogen fixation in the South Pacific Gyre, ISME J., 6, 1238-1249, 2012.

Hauruseau, D. and Koblížek, M.: Influence of Light on Carbon Utilization in Aerobic Anoxygenic Phototrophs, Appl. Environ. Microb., 78, 7414-7419, 2012.

Hoppe, H. G.: Significance of exoenzymatic activities in the ecology of brackish water: measurement by means of methylumbelliferyl-substrates, Mar. Ecol.-Prog. Ser., 11, 299308, 1983

Hunt, B. P. V., Bonnet, S., Berthelot, H., Conroy, B. J., Foster, R. A., and Pagano, M.: Contribution and pathways of diazotrophderived nitrogen to zooplankton during the VAHINE mesocosm experiment in the oligotrophic New Caledonia lagoon, Biogeosciences, 13, 3131-3145, doi:10.5194/bg-13-3131-2016, 2016.

Kirchman, D. L.: Leucine incorporation as a measure of biomass production by heterotrophic bacteria. In: Handbook of methods in aquatic microbial ecology, edited by: Kemp, P. F., Sherr, B. F., Sherr, E. B., and Cole, J. J., Lewis, Boca Raton, 509-512, 1993.

Kirchman, D. L. and Hanson, T. E.: Bioenergetics of photoheterotrophic bacteria in the oceans, Envrionmental Microbiology Reports, 5, 188-199, 2013.

Knapp, A. N., Fawcett, S. E., Martínez-Garcia, A., Leblond, N., Moutin, T., and Bonnet, S.: Nitrogen isotopic evidence for a shift from nitrate- to diazotroph-fueled export production in VAHINE mesocosm experiments, Biogeosciences Discuss., 12, 1990119939, doi:10.5194/bgd-12-19901-2015, 2015.

Lami, F., Cottrell, M., Ras, J., Ulloa, O., Obernosterer, I., Claustre, H., Kirchman, D., and Lebaron, P.: High abundances of aerobic anoxygenic photosynthetic bacteria in the South Pacific ocean, Appl. Environ. Microb., 73, 4198-4205, 2007.

Leblanc, K., Cornet, V., Caffin, M., Rodier, M., Desnues, A., Berthelot, H., Turk-Kubo, K., and Heliou, J.: Phytoplankton community structure in the VAHINE MESOCOSM experiment, Biogeosciences Discuss., doi:10.5194/bg-2015-605, in review, 2016.

Lemée, R., Rochelle-Newall, E., Van Wambeke, F., Pizay, M.-D., Rinaldi, P., and Gattuso, J.-P.: Seasonal variation of bacterial production, respiration and growth efficiency in the open NW Mediterranean Sea, Aquat. Microb. Ecol., 29, 227-237, 2002.

Mari, X., Rochelle-Newall, E., Torreton, J., Pringault, O., Jouon, A., and Migon, C.: Water residence time: A regulatory factor of the DOM to POM transfer efficiency, Limnol. Oceanogr., 52, 808819, 2007.

Mari, X., Lefèvre, J., Torréton, J.-P., Bettarel, Y., Pringault, O., Rochelle-Newall, E., Marchesiello, P., Menkes, C., Rodier, M., Migon, C., Motegi, C., Weinbauer, M. G., and Legendre, L.: Effects of soot deposition on particle dynamics and microbial processes in marine surface waters, Global Biogeochem. Cy., 28, 662-678, 2014.

Marie, D., Partenski, F., Jaquet, S., and Vaulot, D.: Enumeration and cell cycle analysis of natural population of marine picoplankton by flow cytometry using the nucelic acid stain SYBR green I, Appl. Environ. Microb., 63, 186-193, 1997.

Martínez-Martínez, J., Norland, S., Thingstad, T. F., Schroeder, D. C., Bratbak, G., Wilson, W. H., and Larsen, A.: Variability in microbial population dynamics between similarly perturbed mesocosms, J. Plankton Res., 28, 783-791, doi:10.1093/plankt/fbl010, 2006.

Mary, I., Garczarek, L., Tarran, G. A., Kolowrat, C., Terry, M. J., Scanlan, D. J., Burkill, P. H., and Zubkov, M. V.: Diel rhythmicity in amino acid uptake by Prochlorococcus, Environ. Microbiol., 10, 2124-2131, 2008a.

Mary, I., Tarran, G. A., Warwick, P. E., Terry, M. J., Scanlan, D. J., Burkill, P. H., and Zubkov, M. V.: Light enhanced amino acid uptake by dominant bacterioplankton groups in surface waters of the Atlantic Ocean, FEMS Microbiol. Ecol., 63, 36-45, 2008 b.

Moisander, P. H., Beinart, R. A., Hewson, I., White, A. E., Johnson, K. S., Carlson, C. A., Montoya, J. P., and Zehr, J. P.: Unicellular Cyanobacterial Distributions Broaden the Oceanic $\mathrm{N}_{2}$ Fixation Domain, Science, 327, 1512-1514, 2010.

Moore, L. R.: More mixotrophy in the marine microbial mix, P. Natl. Acad. Sci. USA, 110, 8323-8324, 2013.

Moran, X. A. and Alonso-Saez, L.: Independence of bacteria on phytoplankton? Insufficient support for Fouilland \& Mostajir's (2010) suggested new concept, FEMS Microbiol. Ecol., 78, 203 205, 2011.

Moutin, T., Raimbault, P., and Poggiale, J. C.: Production primaire dans les eaux de surface de la Méditerranée occidentale : Calcul de la production journalière, C. R. Acad. Sci. Paris, Sciences de la vie, 322, 651-659, 1999.

Moutin, T., Thingstad, T. F., Van Wambeke, F., Marie, D., Slawyk, G., Raimbault, P., and Claustre, H.: Does competition for nano-molar phosphate supply explain the predominance of the 
cyanobacterium Synechococcus?, Limnol. Oceanogr., 47, 15621567, 2002.

Moutin, T., Van Den Broock, N., Becker, B., Dupouy, C., Rimmelin, P., and Le Bouteiller, A.: Phosphate availability controls Trichodesmium spp. biomass in the SW Pacific Ocean, Mar. Ecol.Prog. Ser., 297, 15-21, doi:10.3354/meps297015, 2005.

Moutin, T., Karl, D. M., Duhamel, S., Rimmelin, P., Raimbault, P., Van Mooy, B. A. S., and Claustre, H.: Phosphate availability and the ultimate control of new nitrogen input by nitrogen fixation in the tropical Pacific Ocean, Biogeosciences, 5, 95-109, doi:10.5194/bg-5-95-2008, 2008.

Nagata, T.: Production mechanisms of dissolved organic matter, in: Microbial Ecology of the Oceans, edited by: Kirchman, D., Wiley Liss, New York, 121-152, 2000.

Neveux, J., Lefebvre, J.-P., Le Gendre, R., Dupouy, C., Gallois, F., Courties, C., Gérard, P., Fernandez, J.-M., and Ouillon, S.: Phytoplankton dynamics in the southern New Caledonian lagoon during a southeast trade winds event, J. Marine Syst., 82, 230-244, 2010.

Pfreundt, U., Spungin, D., Bonnet, S., Berman-Frank, L., and Hess, W. R.: Global analysis of gene expression dynamics within the marine microbial community during the VAHINE mesocosm experiment in the South West Pacific, Biogeosciences Discuss., doi:10.5194/bg-2015-564, in review, 2016a.

Pfreundt, U., Van Wambeke, F., Caffin, M., Bonnet, S., and Hess, W. R.: Succession within the prokaryotic communities during the VAHINE mesocosms experiment in the New Caledonia lagoon, Biogeosciences, 13, 2319-2337, doi:10.5194/bg-13-2319-2016, 2016 b.

Pringault, O., Tassas, V., and Rochelle-Newall, E.: Consequences of respiration in the light on the determination of production in pelagic systems, Biogeosciences, 4, 105-114, doi:10.5194/bg-4105-2007, 2007.

Pulido-Villena, E., Baudoux, A.-C., Obernosterer, I., Landa, M., Caparros, J., Catala, P., Georges, C., Harmand, J., and Guieu, C.: Microbial food web dynamics in response to a Saharan dust event: results from a mesocosm study in the oligotrophic Mediterranean Sea, Biogeosciences, 11, 5607-5619, doi:10.5194/bg-11-5607-2014, 2014.

Regaudie-de-Gioux, A., Lasternas, S., Agustí, S., and Duarte, C. M.: Comparing marine primary production estimates through different methods and development of conversion equations, Frontiers in Marine Science, 1, 19, doi:10.3389/fmars.2014.00019, 2014.

Richardson, T. B. and Porter, C. D.: Inactivation of murine leukaemia virus by exposure to visible light, Virology, 341, 321329, 2005.

Rochelle-Newall, E. J., Torréton, J.-P., Mari, X., and Pringault, O.: Phytoplankton-bacterioplankton coupling in a subtropical South Pacific coral reef lagoon, Aquat. Microb. Ecol., 50, 221-229, 2008.

Sieracki, M. E., Haugen, E. M., and Cucci, T. L.: Overestimation of heterotrophic bacteria in the Sargasso Sea: direct evidence by flow and imaging cytometry, Deep-Sea Res. Pt. I, 42, 1399-1409, 1995.
Smith, D. C. and Azam, F.: A simple, economical method for measuring bacterial protein synthesis rates in sea water using $3 \mathrm{H}-$ Leucine, Mar. Microb. Food Webs, 6, 107-114, 1992.

Steeman-Nielsen, E.: The use of radioactive carbon $\left({ }^{14} \mathrm{C}\right)$ for measuring production in the sea, J. Cons. Perm. Int. Explor. Mer, 18, 117-140, 1952.

Steinberg, D. K., Carlson, C. A., Bates, N. R., Johnson, R. J., Michaels, A. F., and Knap, A. H.: Overview of the US JGOFS Bermuda Atlantic Time-series Study (BATS): a decade-scale look at ocean biology and biogeochemistry, Deep-Sea Res. Pt. II, 48, 1405-1447, 2001.

Talarmin, A., Van Wambeke, F., Catala, P., Courties, C., and Lebaron, P.: Flow cytometric assessment of specific leucine incorporation in the open Mediterranean, Biogeosciences, 8, 253265, doi:10.5194/bg-8-253-2011, 2011.

Torréton, J. P., Pages, J., and Talbot, V.: Relationships between bacterioplankton and phytoplankton biomass, production and turnover rate in Tuamotu atoll lagoons, Aquat. Microb. Ecol., 28, 267-277, 2002.

Torréton, J.-P., Rochelle Newall, E., Pringault, O., Jacquet, S., Faure, V., and Brand, E.: Variability of primary and bacterial production in a coral reef lagoon (New Caledonia), Mar. Pollut. Bull., 61, 335-348, 2010.

Turk-Kubo, K. A., Frank, I. E., Hogan, M. E., Desnues, A., Bonnet, S., and Zehr, J. P.: Diazotroph community succession during the VAHINE mesocosm experiment (New Caledonia lagoon), Biogeosciences, 12, 7435-7452, doi:10.5194/bg-12-7435-2015, 2015.

Van Wambeke, F., Christaki, U., Giannakourou, A., Moutin, T., and Souvemerzoglou, K.: Longitudinal and vertical trends of bacterial limitation by phosphorus and carbon in the Mediterranean Sea, Microb. Ecol., 43, 119-133, 2002.

Van Wambeke, F., Bonnet, S., Moutin, T., Raimbault, P., Alarcón, G., and Guieu, C.: Factors limiting heterotrophic bacterial production in the southern Pacific Ocean, Biogeosciences, 5, 833845, doi:10.5194/bg-5-833-2008, 2008a.

Van Wambeke, F., Obernosterer, I., Moutin, T., Duhamel, S., Ulloa, O., and Claustre, H.: Heterotrophic bacterial production in the eastern South Pacific: longitudinal trends and coupling with primary production, Biogeosciences, 5, 157-169, doi:10.5194/bg5-157-2008, 2008b.

Van Wambeke, F., Tedetti, M., Duhamel, S., and Sempéré, R.: Diel variability of heterotrophic bacterial production and underwater UV doses in the eastern South Pacific, Mar. Ecol.-Prog. Ser., 387, 97-108, 2008c.

Wild, C., Rasheed, M., Werner, U., Franke, U., Johnstone, R., and Huettel, M.: Degradation and mineralization of coral mucus in reef environments, Mar. Ecol.-Prog. Ser., 267, 159-171, 2004.

Zubkov, M. V., Tarran, G. A., and Fuchs, B. M.: Depth related amino acid uptake by Prochlorococcus cyanobacteria in the southern Atlantic tropical gyre, FEMS Microbiol. Ecol., 50, 153$161,2004$. 